\section{STRUCTURE MAPS AND SEISMIC STRATIGRAPHY OF THE YAKATAGA SEGMENT OF THE CONTINENTAL MARGIN, NORTHERN GULF OF ALASKA}

\author{
T. R. Bruns and W. C. Schwab
}

\section{ABSTRACT}

Multichannel seismic-reflection data show the late Cenozoic structure, seismic stratigraphy, and geologic history of the Yakataga segment of the continental margin, between Iey Bay and Kayak Island, northern Gulf of Alaska. The structure of the Yakataga segment consists of broad folds and associated thrust faults beneath the continental shelf and slope, trending generally northeast in the eastern part of the segment to east-west in the western part. Anticlines are generally asymmetric and doubly plunging and are commonly bounded on the seaward side by high-angle thrust faults. The degree of deformation is less intense than is observed in adjacent onshore areas. The age of deformation decreases seaward and the deformation shows an overall southeastward migration with time. Structures of similar age define three structural zones; structural growth was roughly contemporaneous in each structural zone, although the local growth pattern is complex in detail. Deformation within each structural zone was followed by subsidence and burial by rapidly deposited marine sediment. Deformation appears to have been continuous during the late Cenozoic, rather than a series of discrete events, because subsidence of a particular structural zone is accompanied by initiation of growth on a younger, more seaward zone. Varying degrees of reactivation of the older structures within recent time have resulted in renewed uplift of these structures. Average sedimentation, uplift, and subsidence rates are all extremely high, and generally range from about 1 to $2 \mathrm{~m} / 1,000 \mathrm{yr}$; these rates can locally be much higher. The average strike of structures in the Yakataga segment indicates northwest-southeastward compression and is consistent with the current convergence direction between the Pacific and North America plates. Observed shortening within the segment is much less than required by the late Cenozoic convergence rate (about $6 \mathrm{~cm} / \mathrm{yr}$ ), and the major deformation is taken up elsewhere, primarily onshore. Thus, the deformation of the Yakataga segment is caused by minor shortening of the continental margin between Cross Sound and Kayak Island, which together comprise the Yakutat block, as the margin moves northwestward with the Pacific plate and collides with the North America plate.

\section{INTRODUCTION}

This report presents interpreted seismic sections and structure contour maps of late Cenozoic strata of the Yakataga shelf and slope, the segment of the continental margin between Icy Bay and Kayak Island, northern Gulf of Alaska (fig. 1). Numerous exploratory oil and gas wells have been drilled in onshore areas bordering the continental shelf (Plafker, 1967, 1971). An of fshore stratigraphic test well was drilled in 1975 southwest of Icy Bay (Bolm and others, 1976), and Federal oil and gas lease sale 39 was held for the offshore area in 1976. Since this sale, 10 offshore exploratory wells have been drilled and abandoned. The locations of onshore and offshore wells and of tracts leased during the sale are shown on the accompanying structure maps (sheets 1-3). Table 1 lists information for the offshore wells; comparable information for the onshore wells was reported by Plafker (1971). Bruns (1979) summarized and discussed the of fshore structure of the northern Gulf of Alaska, and presented the deepest of the structure contour maps in this report. Additional studies relevant to the geology, structure, and resource potential of the Yakataga segment and surrounding areas include those by Stonely (1967), Plafker (1967, 1971, 1974), von Huene and others $(1971,1979 a, b)$, Plafker and others (1975; 1978 a, b, c; 1979; 1980), Plafker and Addicott (1976), Winkler (1976), Rogers (1977), and Plafker and Claypool (1979). The following summary of the geologic setting is based on these publications. In the remainder of the paper, we first describe and summarize the structure and stratigraphy of the Yakataga segment; following that is a detailed discussion of individual seismic lines used to derive the interpretations.

\section{GEOLOGIC SETTING}

Figure 2 shows the generalized geologic and tectonic setting of the northern Gulf of Alaska. The study area lies in a region of relative convergence between the Pacific and North America plates. To the east the Pacific plate is moving laterally past the North American continent along a transform-fault system composed of the Queen Charlotte, Fairweather, and related faults. To the west, in the Kodiak Island and Alaska Peninsula regions, plate motion is accommodated by underthrusting of the Pacific plate beneath the continental margin, along the Aleutian Trench. The Yakataga shelf lies in a structural transition zone between these areas of transform and convergent motion.

Onshore rocks bordering the study area range in age from late Mesozoic through Cenozoic and crop out in belts of decreasing age from north to south (fig. 2). Highly deformed, locally metamorphosed and intruded strata of Cretaceous and older age occur in the Chugach and St. Elias Mountains. Cenozoic rocks, generally in fault contact with the older rocks to the north, consist of a bedded terrigenous clastic sedimentary sequence that was deposited primarily in a marine environment. This sequence is broadly divisible into three subdivisions that correspond to major changes in the tectonic and depositional environment of the basin: (1) a lower Tertiary sequence (Paleocene through lower Oligocene), characteristically hard, dense, and intensely deformed and faulted, and composed primarily of deep-sea-trench or sloperise turbidite deposits; (2) a middle Tertiary sequence (middle Oligocene through lower Miocene), composed primarily of mudstone and siltstone; and (3) an upper Tertiary through Holocene sequence (the Yakataga Formation), characterized by abundant glaciomarine detritus and composed of mudstone, muddy sandstone and conglomeratic sandy mudstone, (marine diamictite; Plafker, 1971; Plafker and others, 1975, 1978a).

Offshore, a Cenozoic sequence, ranging in age from Paleocene through Holocene, has been sampled by dredging on the continental slope (Plafker and others, 1978b, 1979, 1980). Within the study area, clastic sedimentary rocks and basalt of late Paleocene(?) to early Eocene age are present at the base of the slope south of Icy Bay. To the east of the study area, the sequence consists of lower to middle Eocene basalt flows, overlain by lower Eocene through Oligocene sandstone, conglomerate, siltstone, and shale that differs strikingly in microfauna, induration, and lithology from the coeval onshore sequence. The composite thickness of the Eocene and Oligocene sedimentary sequence is estimated at $3,000 \mathrm{~m}$ on the continental slope (Plafker and others, 1980) and is more than $4,500 \mathrm{~m}$ beneath the continental shelf south 
of Icy Bay (Bruns, 1983). The Paleocene rocks are overlain by the Miocene through Holocene Yakataga Formation which may be as much as $6,000 \mathrm{~m}$ thick over some areas of the continental shelf within and east of the study area.

Sea-floor sampling and high-resolution seismic data show that much of the continental margin is mantled with a veneer of unconsolidated Holocene deposits, mostly very fine mud, although ice-rafted or morainal debris of pebbles, cobbles, and boulders, is common. Bottom sedimentary deposits nearshore include submarine moraines and associated outwash fans of sand and gravel near the present major glaciers. Glacially derived boulder, gravel, and sand deposits are also common beneath the fine-grained mud deposits (Carlson and others, 1977).

Deformation within the study area occurred primarily in two episodes: during the Late Cretaceous through early Eocene, and during the middle Miocene through the present. The more recent episode has resulted in pronounced differential uplift and faulting of rock strata throughout southern Alaska, as well as an apparent increase in the intensity of folding and magnitude of fault displacement from south to north and from east to west across the continental margin and adjacent land areas (Plafker, 1971; Plafker and others, 1975, 1978a; Bruns, 1979).

\section{GEOPHYSICAL DATA}

The structure contours presented in this report are interpreted primarily from 24- and 48-fold multichannel seismic-reflection data acquired in 1975 during a cruise of the Geophysical Service, Inc. motor vessel Cecil H. Green (Bruns and Bayer, 1977). Additional multichannel data were gathered over the continental slope and rise in 1977 and 1978 by the U.S. Geological Survey research vessel S. P. Lee. Tracklines for these three cruises and structural trends interpreted from the S. P. LEE data are shown on the accompanying maps. Single-channel reflection data collected during other cruises (Bruns and Plafker, 1975; von Huene and others, 1975; Bruns and Bayer, 1977; Carlson and Molnia, 1978; Molnia and others, 1978; Plafker and others, 1980; George Plafker and others, unpub. data, 1980) were used to better define near-surface structural trends between the multichannel lines. Additional geophysical data acquired during these cruises, including seismic-refraction, magnetic, and gravity data, were reported by Bayer and others (1978), Schwab and Bruns (1979), Schwab and others (1980), Burkhard and others $(1980 \mathrm{a}, \mathrm{b})$, and Bruns and others (1981).

Although the quality of the multichannel seismic data is generally good, many individual seismic reflectors are discontinuous, and only a few can be correlated within a set of seismic records or followed for more than part of an individual record. Several factors that prevent both reflector continuity and acoustic penetration can be identified or inferred at least locally, and to some extent, regionally: (1) persistent water-bottom multiples and interbed multiples generated within the near-surface sedimentary section; (2) coarse or bouldery near-surface and subsurface glacially derived sedimentary deposits that may scatter and seriously degrade the acoustic signal; and (3) numerous local unconformities, rapid facies or bedding changes, and energy scattering boulder or cobble units within the Yakataga Formation.

Structural information at depth is limited by poor acoustic penetration through the extremely thick Yakataga Formation. Only on seismic records extending over the continental slope are good reflectors seen from units near the base of or underlying the Yakataga Formation. These reflectors are rapidly obseured landward because of interbed and water bottom multiples generated in the thick Yakataga sequence, and because there is insufficient acoustic energy to delineate the deeper events. In general, primary reflectors and, therefore, structures observed on seismic records from the continental shelf are within the Yakataga Formation, and extension of these structures into the underlying early and middle Tertiary strata is largely inferred.

Three seismic horizons are correlated throughout the seismic grid, each at least locally mapped on an unconformity. In areas where these unconformities are absent or cannot be readily followed, mapping is on a seismic horizon correlative with the unconformities. Thus each of the horizons is, or approximates, a time boundary. Interpretation problems in following the seismic horizons arise from the absence of continuous regional seismic reflectors, the complex structure, and the wide spacing of the seismic grid. Because of these problems, correlation errors may be present in some areas. Seismic traverses on horizons $\mathrm{A}, \mathrm{B}$, and $\mathrm{C}$ were used to construct structure maps presented, from shallowest to deepest, on sheets 1,2 , and 3 respectively. The structural features mapped for horizon $C$ are more interpretative than for horizons A and B because more latitude was allowed in inferring structural features and trends. Seismic lines showing the mapped horizons are presented in detail after the structure and discussion sections of the paper.

A strong seismic reflector below horizon C, herein referred to as the D reflector, is observed on those parts of seismic lines that cross the continental slope. The D reflector is apparently regional in extent and thus would make an ideal mapping horizon. However, this reflector can only be correlated locally throughout the seismic grid becasue it is obscured by reflections generated within the thick sedimentary section of the continental shelf. The significance of this reflector is discussed below.

\section{VELOCITY DATA}

The structure maps accompanying this report are contoured in depth; the depth conversion is determined from the seismic time records using stacking velocities obtained from common-depth-point gathers. Detailed velocity analyses were performed at 13 locations chosen in structurally simple areas. The resulting stacking velocities were converted to interval velocities by use of the Dix equation (Dix, 1955), and the interval-velocity curves were used to construct a time-depth curve for each location. Agreement between most of the computed time-depth curves is close, although the velocity at two locations on structural highs is perhaps 10 to 15 percent higher than off structure. The set of time-depth curves resulting from the detailed velocity analysis was fitted by a least-square-error routine to yield a single curve, $\mathrm{z}=0.17 \mathrm{t}^{2}+0.85 \mathrm{t}$, where $\mathrm{z}$ is the depth in kilometers and $t$ is the two-way traveltime in seconds (fig. 3). This area-average time-depth curve was then used for all time-to-depth conversions; in areas with a water depth greater than $200 \mathrm{~m}$, the depth conversion was corrected for slower velocity through the water layer. The method of derivation for this curve is valid only to a maximum two-way subbottom traveltime of about $4 \mathrm{~s}$; for greater traveltimes, information from the stacking velocities is insufficient to determine the velocity adequately. Therefore, depth conversions for subbottom times greater than about $4 \mathrm{~s}$ are based on extrapolation along the calculated curve.

Use of a single time-depth curve leads to errors in depth conversion of the horizons presented on the accompanying structure maps. The velocity in a deformed sedimentary section is determined more by the maximum burial depth of the sedimentary sequence than by the current burial depth. Thus, the depth conversion is likely to be most in error in areas of recent uplift. The likely error in the depth conversion can be estimated by comparison with data from wells in the study area and by an analysis of the maximum likely error over the most recently uplifted anticlines.

Comparison of the seismically derived time-depth curve with curves derived from sonic logs of the Standard Oil Riou Bay No. 1 well in Icy Bay (well 58, sheets $1-3$ ) and the Continental Offshore Stratigraphic Test No. 1 (COST No. 1, well 74; Bolm and others, 1976) shows excellent agreement (fig. 3). The Riou Bay No. 1 and COST No. 1 wells are located in structurally simple areas similar to those where most of the detailed velocity analyses were made. However, an additional comparison with the Standard Oil Chaix Hills No. 1A well (well 60), located in a structurally complex area, shows a significant disagreement (fig. 3 ).

The youngest anticlines in the study area are west of 
Icy Bay. The largest anticline (A1, fig. 4; sheets 1-3; see also seismic lines 418 and 406 , sheet 4) can be used to determine the maximum likely depth-conversion error. The section at the crest of the anticline is assumed to retain approximately the velocity of maximum burial depth, estimated by the amount of section lost over the anticline (about $1500 \mathrm{~m}$ ). With this assumption, the derived time-depth curve gives a depth estimate about 35 percent shallower than that given by the inferred maximum velocity. Thus, the maximum relief on anticline $\mathrm{A} 1$ for horizon $\mathrm{C}$ (fig. 4; sheets 3 and 4) is probably about $1.5 \mathrm{~km}$ rather than the $2.0 \mathrm{~km}$ shown on the structure map (top at $1.9 \mathrm{~km}$ rather than $1.4 \mathrm{~km}$ ). The likely error over most of the other anticlines is much less than this maximum because: (1) most structures are buried under a substantial thickness of late Cenozoic strata, and so the present depth of burial may be similar to the maximum depth of burial before uplift; and (2) detailed velocity analysis over two structural highs suggests an error of only about 10 to 15 percent.

In summary, these considerations suggest that: (1) the derived time-depth curve is reasonably accurate for depth conversion in synclinal and low relief structural areas; (2) the curve yields a depth probably less than 10-15 percent in error over most of the structurally high areas; (3) the maximum likely error, seen only in the area of greatest uplift of the youngest anticlines (primarily the easternmost folds of the continental shelf, including anticlines $\mathrm{A} 1, \mathrm{~A} 2$, and $\mathrm{SA} 1$, fig. 4 ), is about 35 percent; and (4) the velocity data from which the curve is derived are adequate only to about $4 \mathrm{~s}$ of twoway traveltime in sedimentary deposits; depths for greater times are based on an extrapolation of the calculated timedepth curve. Although use of a single velocity function introduces errors in the depth conversion of the contoured horizons, these errors are not so large as to affect the basic conclusions of this report.

\section{AGES OF MAPPED HORIZONS}

The ages of the mapped horizons can be estimated from four points of geologic control: (1) the Standard Oil of California Riou Bay well (well 58, sheets 1-3); (2) the COST well (well 74); (3) areas where mapped horizons crop out at the sea floor; and (4) dredge samples from the continental slope. Onshore wells are in structurally complex positions and cannot readily be correlated with of fshore areas on the basis of the available seismic data.

The Riou Bay well reached a total depth (TD) of 4,301 $\mathrm{m}$. Foraminiferal assemblages (Rau and others, 1977) indicate that the well was drilled through a Pliocene and Pleistocene section of the Yakataga Formation and probably bottomed within lower Pliocene (?) strata of the lower part of the Yakataga Formation. The base of the Pleistocene is within the interval from about 1,950 to $2,550 \mathrm{~m}$, and the most likely position is toward the top of this interval. The closest seismic record, 404 (sheet 4), is $15 \mathrm{~km}$ from the well; structural relief, however, is rather gentle within this gap. The seismic tie is made by estimating $0.2 \mathrm{~s}$ of dip on the seismic record from the well to the end of seismic section 404 (at the north end of seismic section 404: horizon A, 1.42 $\mathrm{s}$; horizon $\mathrm{B}, 1.9 \mathrm{~s}$; horizon $\mathrm{C}, 2.5 \mathrm{~s}$ ). This procedure gives a seismic correlation to the well of about $1,300 \mathrm{~m}$ for horizon $\mathrm{A}, 1,940 \mathrm{~m}$ for horizon $\mathrm{B}$, and $2,850 \mathrm{~m}$ for horizon $\mathrm{C}$. In addition, the $D$ reflector (about $3.5 \mathrm{~s}$ at the north end of record 404 ) ties to the well at about $4,600 \mathrm{~m}$. Therefore horizon $\mathrm{A}$ is about middle Pleistocene, horizon $\mathrm{B}$ is about the Pliocene-Pleistocene boundary, horizon $C$ is Pliocene, perhaps late Pliocene, and the $\mathrm{D}$ reflector approximately marks the base of the Yakataga Formation and could range in age from middle or late Miocene through about early Pliocene.

The COST well (TD $1,570 \mathrm{~m}$ ) drilled through strata of middle and late Pleistocene age (Bolm and others, 1976). Horizon A correlates to strata at the bottom of the well; a middle Pleistocene age is consistent with the age inferred for horizon A from the Riou Bay well tie.

Horizon C crops out along the offshore extension of the Sullivan fault near Cape Yakataga (sheet 3). The section on Yakataga reef at Cape Yakataga includes the lower part of the Yakataga Formation of upper Miocene or Pliocene age (Rau and others, 1977). Seismic data are insufficient to estimate how much section is lost between horizon $\mathrm{C}$ and the extrapolated correlation to Yakataga reef, although a Pliocene age for horizon C, probably late Pliocene, is consistent with its outcrop pattern.

Finally, dredge samples from the continental slope (Plafker and others, 1978c, 1979, 1980) suggest that the D reflector is approximately at the base of the Yakataga Formation, an interpretation consistent with the extrapolated tie to the Riou Bay well.

In summary, the available data give best age estimates of middle Pleistocene for horizon A, earliest Pleistocene for horizon $\mathrm{B}$, about late Pliocene for horizon $\mathrm{C}$, and possibly middle Miocene through early Pliocene for the $\mathrm{D}$ reflector at the base of the Yakataga Formation. These ages must be considered as preliminary until actual picks from the exploratory wells are incorporated into the seismic interpretation. Also, the strata may be time transgressive, and the age of a particular seismic horizon may vary throughout the shelf. The age of horizon $\mathrm{C}$ given here is younger than that assigned by Bruns (1979).

Two lines shown in this report, lines 404 and 922 (sheet 4) extend across the continental slope and show strata at the base of the slope. Three horizons are mapped in this strata, designated as horizons A1, A2, and A3. Based on a multichannel seismic tie to Deep Sea Drilling Project hole 178 east of Kodiak Island, horizon A1 is approximately at the base of Pleistocene strata, horizon $\mathrm{A} 2$ is at the base of Pliocene strata, and horizon $\mathrm{A} 3$ is on the top of the oceanic basalt (T. R. Bruns, unpub. data, 1978).

\section{STRUCTURE}

The structure of the Yakataga segment of the continental margin (the Yakataga shelf and slope) reflects a transition from the relatively undeformed Yakutat segment to the east to the highly deformed Middleton segment to the west (fig. 2). Two zones of major structural change define the Yakataga segment boundaries - the easternmost folds of the Pamplona zone and the Kayak zone. The Pamplona zone is generally considered to be the set of folds and associated faults that trend across the continental shelf and slope of the Yakataga segment (Plafker and others, 1978). The Kayak zone includes Kayak Island and its offshore extension (herein referred to as the Kayak Island platform), a zone of complex faulting and major structural shortening that crops out on Kayak and Wingham Islands (Plafker, 1974; Plafker and others, 1978a) and extends across the continental margin (Bruns, 1979).

The structure of the Yakataga segment and nearby terrain is shown by structure contour maps of strata underlying the continental shelf and upper slope (sheets 1-3) and by mapped structural trends across the continental slope (sheet 3). East of the Pamplona Spur, a broad ridgelike high below the shelf break trends northwest. The mapped strata dip landward toward a structural low with its axis near the coast, and seaward where they are truncated on the continental slope or merge into an abyssal fan at the base of the slope. North and west of and beneath the Pamplona Spur, the strata are deformed into numerous broad folds and associated faults with a regional northeast to east-west trend. Significant variations from this regional trend are present in individual structures, particularly between about longitude 142 , and $143, W$., where several structures, including the Pamplona Spur and the Sullivan fault and its offshore extension, bend sharply to the south. Anticlines beneath the continental shelf generally are markedly elongate, asymmetric, and doubly plunging. The anticlines are commonly bounded on the seaward side by high-angle landward-dipping reverse faults. Antithetic faults occur locally on the northwest or north flanks. Minor normal faults are also locally present, primarily north and east of the Pamplona Spur. The width of individual structures ranges from about 4 to $10 \mathrm{~km}$, and closure is present along strike for distances of 15 to $40 \mathrm{~km}$. Dips on the flanks of the anticlines, commonly less than 15 , locally reach 30 , or more.

The three mapped horizons can be used to determine the timing and pattern of structural development, approximate sedimentation, uplift, and subsidence rates, the 
minimum amount of shortening across the continental shelf, and an approximate direction for the regional compression that has caused structural growth, as discussed in below.

\section{STRUCTURAL DEVELOPMENT}

The timing and pattern of structural growth shown by the seismic horizons, though complex in detail, has the oldest structural growth to the northwest and the youngest to the southeast, with recent reactivation of the older structures. This general pattern can be observed on the structure maps, and in more detail by considering the mapped horizons on the seismic sections and the configuration of reflectors between these horizons. A detailed interpretation of several seismic sections is presented at the end of this report; in the following section we summarize the seismic interpretation by describing the reflector configuration and the tectonics within the mapped intervals, and by discussing generalized structural trends of similar age that cross the continental shelf and slope. The locations of the seismic sections considered here are shown on the structure maps (sheets 1-3) and figure 4 presents a key to the structures described. The seismic sections and true scale depth sections showing the mapped horizons are shown on sheet 4; figure 5 shows the depth sections superimposed on the structural trends to illustrate the structural relations. In our discussion of the seismic data, the terminology for referring to time (or strata) between any two horizons, for example, the B and A horizons, will be "B-A time (strata)."

\section{Strata Below Horizon D}

The D reflector (the approximate base of the Yakataga Formation) is locally, and perhaps regionally, an unconformity (seismic sections 404, 409, 410, 414; sheet 4). Seismic data below this horizon, where clearly observable on the continental slope, show few coherent reflectors, possibly because of either a very uniform lithology or deformation of the underlying strata before D time. Seismic reflectors below horizon $\mathrm{D}$ on the continental shelf are generally obscured by multiples. Total depth to horizon D (approximately the thickness of the Yakataga Formation), is as great as 7,000 m, is commonly about 5,000 to $6,000 \mathrm{~m}$, and thins to a minimum of about $3,500 \mathrm{~m}$ beneath some structural highs. Dredge data in the vicinity of line 404 and seismic correlations to the dredge data indicate that strata below horizon $\mathrm{D}$ are at least in part an Oligocene and older clastic sedimentary section overlying Eocene basalt (Plafker and others, 1980).

\section{$\mathrm{D}-\mathrm{C}$ Interval}

Reflectors within the D-C interval, though rather poor, show little evidence for either the presence of major unconformities within the D-C seismic sequence or truncation of the sequence at the C horizon. Thus, in general, these strata were deposited without significant contemporaneous deformation and were subsequently deformed as a unit at about $\mathrm{C}$ time, extending through early $\mathrm{C}-\mathrm{B}$ time. On seismic sections west of about line 411 (fig. 4), horizon $C$ is a strong seismic reflector that is an unconformity (lines 412,414 , and 417 , sheet 4). The absence or near absence of truncation of $\mathrm{D}-\mathrm{C}$ sequence reflectors at horizon $\mathrm{C}$ suggests that this unconformity is not erosional but reflects either nondeposition or a change in the depositional patterns due to initiation of uplift at about C time. Also, if the horizon C unconformity is not erosional, the amount of apparent uplift of D-C strata after C time (lines 412 and 414, sheet 4) suggests that these strata were initially deposited in moderately deep water, perhaps on a continental slope. East of line 411 , strata are generally conformable across horizon $\mathrm{C}$, which here is not a major unconformity (sheet 4); these relations suggest continuous deposition and only minor tectonism during $\mathrm{D}-\mathrm{C}$ time.

\section{C-B Interval}

On seismic sections west of line 411 (fig. 4), strata within the C-B interval generally show pronounced onlap onto the $\mathrm{C}$ horizon. The depositional pattern suggests continued uplift during C-B time of anticlines A10, A11, and A12 relative to the landward depocenter. Locally during late C-B time, structural uplift ceased, and subsidence began; the upper part of the C-B sequence was deposited over some of the subsiding anticlines. Also during $C-B$ time, major structural growth occurred on anticlines A8, A9, and other smaller anticlines A13 and A14 (fig. 4). Thus, anticlines A8 through A14 all record early deformation of the continental shelf. Structural uplift on anticline A7 and A5 may also have begun during this time interval, although the time of uplift cannot be clearly interpreted from the seismic data.

\section{B-A Interval}

In the area west of line 411 , horizon B generally marks a change from uplift to subsidence over anticlines A8 through A14, although subsidence may locally have begun earlier than B time. Also, initiation or continuation of growth on more seaward structures occurred during this interval on anticlines $\mathrm{SA} 2, \mathrm{SA} 3, \mathrm{SA} 4, \mathrm{~A} 5, \mathrm{~A} 6$, and A7 and possibly A2 and A3. Horizon A is a major unconformity over many of these structures; truncation of B-A strata at horizon A indicates erosion of the crests of the anticlines, probably by subaerial or glacial processes during late B-A time.

\section{A-Present Interval}

During the interval A-present, major anticlinal growth shifted seaward to anticlines A1, SA1, SA2, SA5 and possibly A2 and A3. Major truneation at the sea floor of strata over anticlines A1, A2, and A3 apparently occurred during late Pleistocene time. In addition, reactivation of the older structures (A8 through A12) during this interval resulted in uplift and truncation of post-horizon A strata at the sea floor over these structures. Structures that were formed during BA time are deeply subsided and buried by post-horizon A strata.

Figure 6 presents a generalized summary of the growth history of structures on the continental shelf and slope; the overall pattern shows a southward to southeastward shift of deformation over time. While intermediate-age anticlines were actively growing, older anticlines were subsiding. Similarly, while young anticlines were growing, intermediate age anticlines were subsiding, but the oldest anticlines were undergoing renewed uplift. In general, uplift on a particular structural zone was coeval with subsidence on another zone; thus, deformation appears to have been generally continuous rather than episodic. The time of initiation of uplift or subsidence on individual structures within a structural zone of a particular age varies, and although the general pattern is clear, the local growth pattern is complex in detail.

Significant variations in structural trends of differing age are present in two zones (arrows, fig. 6). At the northeastern zone, structural trends, including the Pamplona Spur and the Sullivan fault and its offshore extension, make a sharp southward bend. At the southwestern zone, the age correlative structural trend north of the zone shows either a northwestward shift relative to the age trend south of the zone or a major change in strike and structural complexity across the zone. The apparent offset in structural trends of similar ages raises the possibility of left-lateral strike-slip faulting along this zone. Because no faulting has been detected on these apparent discontinuities, they probably represent nonuniform folding of shelf and slope strata rather than major fault of fset of once-continuous structures.

\section{Sedimentation, Uplift, and Subsidence Rates}

The age and depth of the mapped horizons can be used to estimate sedimentation rates for the continental shelf and, assuming shelf depths over time, uplift and subsidence rates as well. In general, the rates for each of these processes can vary markedly, because the processes are highly localized; nevertheless, our estimates are sufficient to characterize rapid sedimentation and tectonic changes.

The average thickness of strata is approximately 3,000 
to $3,500 \mathrm{~m}$ above the $\mathrm{C}$ horizon, $1,000 \mathrm{~m}$ between the $\mathrm{B}$ and $\mathrm{A}$ horizons, and 1,000 to $1,500 \mathrm{~m}$ above the $\mathrm{A}$ horizon. The ages of horizons are middle to late Pliocene (approx. 3.5 m.y. B.P.) for the C horizon, earliest Pleistocene (approx. 2 m.y. B.P.) for the B horizon, and middle Pleistocene (approx. 1 m.y. B.P.) for the A horizon. Thus, the overall depositional rate is about $1 \mathrm{~m} / 1,000 \mathrm{yr}$ for the late Pliocene through Pleistocene strata above the $\mathrm{C}$ horizon, and is similar for each interval between horizons. Locally, within subsiding areas of the continental shelf, depositional rates are somewhat higher, about $1.5 \mathrm{~m} / 1000 \mathrm{yr}$. These rates are comparable to the depositional rate of $1 \mathrm{~m} / 1000 \mathrm{yr}$ for early Pleistocene strata on Middleton Island (Plafker and Addicott, 1976). These values are also minimum values, as no compaction effects are considered; therefore actual depositional rates could be substantially higher.

Uplift and subsidence rates, where best determined relative to the assumed paleosea level at horizon $\mathrm{A}$, are also high. Maximum uplift on anticline A1 is approximately 1,500 $\mathrm{m}$ since horizon A time, or $1.5 \mathrm{~m} / 1,000 \mathrm{yr}$. Similarly, uplift on anticlines A10, A11, and A12 during post-horizon A time is approximately 500 to $1,000 \mathrm{~m}$, or 0.5 to $1 \mathrm{~m} / 1,000 \mathrm{yrs}$. Subsidence during post-horizon A time over anticline A7 is about $1,200-1,800$ meters, or 1.2 to $1.8 \mathrm{~m} / 1,000$ yrs. Maximum subsidence on seismic section 404 during posthorizon A time is also about 1,000 to $1,500 \mathrm{~m}$, assuming a shelf depositional environment throughout this time, or 1$1.5 \mathrm{~m} / 1000 \mathrm{yr}$. Thus, general uplift and subsidence rates range from about 0.5 to $1.8 \mathrm{~m} / 1,000 \mathrm{yr}$. Similar rates can be determined for strata below the A horizon. The seismic data and onshore uplift rates (discussed below) suggest that structural growth, once initiated, may be much more rapid than is indicated by these average rates; the best example is on anticline A1 (fig. 4; line 406, sheet 4) Minor thinning on the flanks of this anticline occurs only within the uppermost part of the A-sea-floor (A-SF) seismic sequence and indicates that growth began well after horizon A time, perhaps during a third to a quarter of the A-SF interval. Thus, the uplift rate of anticline A1 could be significantly greater, perhaps by as much as 3 to 4 times greater, than the average rate given above of $1.5 \mathrm{~m} / 1,000 \mathrm{yr}$.

In comparison with these rates, uplift and subsidence rates on Albatross Bank and within the Albatross basin on the Kodiak shelf south of Kodiak Island (fig. 2) are both about 0.6 to $3 \mathrm{~m} / 1,000 \mathrm{yr}$ (Fisher, 1980; Fisher and von Huene, 1980; MeClellan and others, 1980). This area, which is in a zone of direct convergence between the Pacific and North American plates, is generally considered to have very high uplift and subsidence rates. The average rates for the Yakataga shelf are very similar to the Kodiak shelf rates. However, the maximum measured uplift rate within the northern Gulf of Alaska area is on Middleton Island (fig. 2) where the average uplift rate for the past $4,300 \mathrm{yr}$ has been about $10 \mathrm{~m} / 1,000 \mathrm{yr}$, on the basis of measurements of uplifted marine terraces (Plafker and Rubin, 1978). This rate also suggests that uplift, once initiated, may be much more rapid than is indicated by the average rates discussed above.

\section{Average Compression Direction}

The average strike of structures underlying the continental shelf and slope should reflect the general direction of regional compression during late Cenozoic time; the average compression direction is assumed to be normal to the axis of these structures. The average strike and length of structures underlying the continental margin are easily determined from the mapped structural horizons and from the structural trends across the continental slope (sheet 3 ). The strike direction of each structure was weighted by its length, and a length-weighted average strike determined for structures on the continental shelf and slope (fig. 7). For offshore structures only, the length weighted average strike is N. 65, E., indicating an average compression direction of about N. 25, W. If we include onshore trends for the Yakataga and Sullivan anticlines and for Kayak Island, the average strike changes only slightly to about N $67, \mathrm{E}$ (fig. 7 ).
A minimum estimate of structural shortening within late Cenozoic strata of the Yakataga segment can be determined from the deepest of the structural maps and from preliminary interpretation of data across the continental slope. This minimum estimate assumes that the strata were initially flat lying and that thrust faulting has not caused significant imbrication on the mapped horizon; thus, the estimate is only a measurement of the shortening due to folding. The minimum amount of shortening, as determined on four cross sections, is about $2 \mathrm{~km}$; actual shortening is almost certainly greater than this minimum, because significant imbrication is likely to have occurred on at least some structures. Such imbrication is, in general, difficult to detect from seismic data because the anticlines effectively mask deeper data. Also, very slight deviations from the nearly vertical dips on the bounding faults, as observed on the vertically exaggerated seismic sections, would translate to substantial overthrusting. It is difficult to determine the dip of these faults accurately from most of the seismic data, and actual shortening could easily be 2 to 3 or more times the minimum estimate. Shortening seems unlikely to be as much as an order of magnitude greater, however, because such shortening would result in zones on the seismic data where well-defined seismic reflectors are absent owing to severe deformation or steep dips of the strata. From seismic reflection data on the Yakataga shelf, structures generally have well-defined reflectors over anticlines, dips are rather moderate, and the structures are not severely deformed.

\section{DISCUSSION}

A major feature of the late Cenozoic structure of the Yakataga shelf is a deformational pattern of sequential structural development progressing seaward over time, accompanied by some combination of subsidence or renewed uplift of the older, more landward structural zones. However, probable contemporaneous major deformation and uplift was ongoing in the adjacent onshore areas of Kayak Island and the Yakataga district during the late Cenozoic (Plafker, 1971; 1974). Deformation and structural relief in these areas are more severe than is observed offshore and increase in intensity toward the Chugach-St. Elias Mountains (fig. 2). Thus much, and perhaps most, of the late Cenozoic compressional stress across the continental margin has apparently been taken up in areas of existing deformation within the onshore and older offshore structural zones. Perhaps only a small component of the regional stress field is taken up offshore in the initiation of new deformation zones.

A second feature of the mapped structure is the variations in structural trend within structural zones of a particular age; these variations indicate either nonuniform folding or a late period of differential deformation that offset similar-age structural zones. A possible explanation for these variations in trend is that structures underwent rotation and dissection during late stages of the initial deformation episode or during a later deformation episode. The set of anticlines A1, SA1, and the southerly structural extension of SA1 (fig. 4), provide a possible model for such a process. Deformation on anticline A1 is greatest at its west end, and the strike of the structure is more easterly than the average structural trend. Deformation on anticline SA1 is most extreme at its north end (corresponding to the Pamplona Spur); the south end trends into a set of more open, gentle folds. The strike of the northern part of the structural zone is more northerly than regional average, but the strike of the southern folds is generally northeastward, and close to the average. Thus, the overall effect is similar to what might result from a triangular indenter directed toward the center of an originally continuous northeast-trending structure, such that the greatest deformation would be at the point of the indenter and structures would be rotated away from the indenter. A part of the continental shelf and slope southeast of the developing structural zones may act as an indenter, resisting deformation as it moves toward the northwest. Initiation of a new structural zone may eventually break across and isolate these more rigid segments of the margin. 
A third feature of the structure is that, within the resolution of the seismic data, deformation across the onshore and offshore areas has been continuous, rather than episodic during the late Cenozoic. A likely mechanism for such continuous deformation is convergence between the Pacific and North American plates. The current relative convergence vector in the vicinity of the Yakataga shelf, as derived from worldwide plate motion data, is about $6 \mathrm{~cm} / \mathrm{yr}$ at N. 16, W. (Chase, 1978; Minster and Jordan, 1978). The average compressional direction indicated by structures on the shelf and slope is about N. 25, W. Thus, the average trend of these structures is reasonably consistent with the expected deformation due to convergence between the Pacific and North American plates. However, the amount of shortening offshore is substantially less than might be expected from the convergence rate, and most of the shortening is therefore taken up elsewhere, primarily onshore in the fold and thrust belt of the Chugach-St. Elias mountains, rather than offshore by subduction at the base of the continental slope (Bruns, 1979; Bruns, 1983). The Yakataga segment and the Yakutat segment, the margin segment from Cross Sound to the Pamplona zone, together comprise a continuous terrain, the Yakutat block. The observed deformation of the shelf and slope appears to result from minor folding and buckling of the Yakutat block as it moves with the Pacific plate during the late Cenozoic.

\section{SUMMARY}

The late Cenozoic structure of the Yakataga segment of the continental margin consists of broad folds and associated faults trending generally northeastward in the eastern part of the shelf to eastward in the western part. Anticlines are generally asymmetric and doubly plunging and are commonly bounded on the seaward side by high-angle thrust faults. The age of structures generally decreases seaward and shows an overall deformational pattern of southeastward migration over time. Deformation has been followed by burial of the older structures through a combination of regional subsidence of the shelf behind the migrating deformation front and rapid deposition of marine sediment. Varying degrees of reactivation of the older structures within recent time has resulted in renewed uplift, truncation, and possibly rotation and dissection of these structures. An additional consequence of the shifting deformation pattern is numerous local and, perhaps, regional unconformities within the sedimentary section. Although the general pattern is clear, the time of initiation of uplift or subsidence on individual structures within a structural zone of a particular age varies, and the local growth pattern is complex in detail. Average sedimentation, uplift, and subsidence rates are all extremely high, average about 1$2 \mathrm{~m} / 1,000 \mathrm{yr}$, and can locally be much higher. Deformation appears to have been continuous during late Cenozoic time, in response to persistent northwest-southeast directed compression. The average strike of structures within the Yakataga segment of the continental margin is consistent with the convergence direction between the Pacific and North America plates in the northern Gulf of Alaska, but the minor amount of shortening requires that the major convergent deformation is taken up elsewhere, primarily onshore. The deformation of the Yakataga segment is a result of minor shortening (relative to major onshore shortening) of the continental margin as it moves with the Pacific plate towards the North America plate.

\section{DETAILED DESCRIPTION OF SEISMIC SECTIONS}

In this section we present a detailed interpretation of the seismic lines shown on sheet 4 . The locations of these lines are shown on the structure maps (sheets 1-3), and figure 4 shows a key to the structures described. These interpretations, and the interpretation of other lines not shown (Bruns and Bayer, 1977), are the basis for the structure maps and summary presented in previous sections, and illustrate additional details of the structure, the timing of structural growth, and the problems involved in the seismic interpretation.

\section{Seismic Section 404}

Seismic section 404 shows the general features of the continental margin east of the Pamplona zone. Stratal ages on the continental slope are from dredge data (Plafker and others, 1980) and seismic ties into these data. Identification of strata within the oceanic section is from a multichannel seismic tie to Deep Sea Drilling Project (DSDP) Hole 178 (T. R. Bruns, unpub. data, 1978).

Beneath the continental shelf and slope, seismic reflectors indicate that strata above horizon $D$ are undeformed, flat lying to gently dipping, and that the sedimentary section thickens landward. The mapped horizons crop out on the continental slope, and the seaward depositional limits of successively younger strata lie landward of underlying strata. The D reflector is easily visible at the oceanward end of the section but is rapidly obscured landward by multiples. Where the pre-horizon D section is not obscured, few seismic reflectors are seen below horizon D, as is best seen in the zone at the base of the continental slope below and seaward of the horizon D outcrop position. At the oceanward end of the record, reflectors also are generally flat lying. Reflectors within the oceanic section terminate at the base of the continental slope.

This seismic section shows an undeformed sequence of post-horizon D strata (approximately the Yakataga Formation) overlying a deeply buried Eocene and Oligocene section. The post-horizon D geologic history of this segment of the continental shelf and slope is primarily one of shelfbasin subsidence, and the outcrop pattern on the continental slope in this section, in which young strata generally crop out more landward than the underlying strata, indicates that deposition has not kept pace with subsidence. The absence of coherent well-defined reflectors within the sequence below horizon D suggests either a rather uniform lithology.

\section{Seismic Section 418}

Section 418 crosses the east end of anticline A1 (fig. 4). Structural relief is very gentle, and there is no clear evidence of faulting or thinning of the section on the flanks of or over the structural high. Growth of the anticline is clearly post-horizon A time. A distinct unconformity is present in the upper $0.4 \mathrm{~s}$ of the record on the south side of the anticline (dashed line). This unconformity is likely at the base of a trough formed by glacial erosion, and the trough is now filled with Holocene sedimentary deposits (Carlson and others, 1977). High-resolution data over the anticline show some onlap, thinning, and very gentle upbowing of the Holocene cover against and over the anticline. These features could be depositional or could indicate minor Holocene uplift of the anticline. The anticline has no bathymetric expression at the sea floor in this locality, primarily because Holocene sediment has infilled the adjacent scour areas. The $\mathrm{D}$ reflector should be present at about $3.5 \mathrm{~s}$ on the basis of a seismic tie to record 404 , but it is obscured by multiples or a lack of acoustic-energy penetration.

This seismic record also shows some of the problems with the seismic data, including discontinuous reflectors and multiples, particularly below the south flank of the anticline. Seismic events below about $3 \mathrm{~s}$ generally have steeper dips than the overlying events, and the dip increases at greater traveltimes. These steep events are interpreted as multiples, probably interbed multiples. Similar features can also be observed on most of the other seismic sections shown in this report.

\section{Seismic Section 406}

Seismic section 406 crosses the zone of maximum uplift of anticlines A1 and A2, and ends near the offshore extension of the Sullivan fault (anticline A3, fig. 4). Minor thinning of the sedimentary section is present above horizon $A$ on the north side of anticline A1; otherwise, little or no thinning is observed on either anticline A1 or A2, although strata exhibiting such thinning may have been removed by erosion at the crests of the anticlines. The position of the D 
reflector is derived by formlining a tie to record 404, but is poorly controlled.

Major faulting is present on all these structures; maximum offset at horizon $\mathrm{C}$ is approximately $500 \mathrm{~m}$ and $1,400 \mathrm{~m}$ on anticlines $\mathrm{A} 1$ and $\mathrm{A} 2$ respectively. The fault on anticline A1 dips north; the interpreted position of the fault is controlled by diffractions between 2 and about $4.5 \mathrm{~s}$. Highresolution data (von Huene and others, 1975) over both anticlines suggest that small normal faults are present at the crests of the anticlines; in addition, a minor antithetic fault may be present on the north side of anticline A2. Substantial truncation of strata has occurred over the crests of the anticlines (as much as $1,500 \mathrm{~m}$ over anticline $\mathrm{A} 1$ and significantly more over anticline A2) by subaerial or glacial erosion during late Pleistocene time.

Growth on anticline A1 occurred after horizon A time, as indicated by minor thinning on the north side of the structure in post-horizon A strata. The presence of such thinning only in the upper part of the A-sea floor (A-SF) interval indicates very recent, probably very rapid growth of the structure. In addition, pronounced topographic expression of this anticline at the sea floor indicates growth during Holocene time. Growth on anticline A2 was definitely posthorizon B, and likely post-horizon A, although strata that might exhibit such growth have been removed. Comparison of anticline A1 on seismic sections 406 and 418 shows that deformation and faulting are greatest at the west end of the anticline, and so the greatest compression is concentrated at this end and decreases to the east. The same pattern is also evident on anticline A2. Structural uplift is greatest on the northernmost anticline, and so anticline $\mathrm{A} 2$ is structurally higher than $\mathrm{A} 1$.

\section{Seismic Section 407}

From south to north, seismic section 407 crosses a very gentle anticline $\mathrm{A4}$, a tightly appressed anticline $\mathrm{A5}$, and the offshore extension of the Sullivan fault, structure A3 (fig. 4). Thinning is present between reflectors on the north flank of anticline A5 between horizons B and A; otherwise, little thinning is observed on the record. Strata above the A horizon have been largely removed over anticlines A3 and A5, by subaerial or glacial erosion during the late Pleistocene.

Growth of anticline A4 is clearly post-horizon A, and minor faulting may be present on both sides of the structure. This anticline appears to be the northernmost continuation of the Pamplona Spur (SA1, fig. 4), a major bathymetric ridge trending across the continental shelf and slope that is underlain by a tightly folded, complex structure.

Thinning of strata on the north flank of anticline A5 indicates that this anticline began to form during B-A time. Truncation of strata over horizon A at the crest of the structure and bathymetric expression of the structure at the sea floor suggest that growth has continued to the present. Offset on the mapped horizons is at least as great as the maximum offset on anticline A2 and probably much greater. Anticline A5 is more severely deformed and more limited in aerial extent than other anticlines on the Yakataga shelf. Single-channel seismic data (Bruns and Plafker, 1975; von Huene and others, 1975) show clearly that this structure is not a continuation of anticline A1 but suggest that it is structurally continuous with and offset from anticline A2. This abrupt change in structural continuity suggests that an initially continuous anticline may have been broken by maximum compression directed towards the center of the original structure, so that the two parts of the original anticline were rotated away from the area of maximum compression and offset.

Seismic data across the offshore continuation of the Sullivan fault generally indicate an anticlinal structure (A3 on sections 406 and 407 , fig. 4). This structure shows a marked change in structural trend similar to that observed on anticlines A2 and A5. The trend of the Sullivan fault is generally east-westward onshore, bends sharply to southward at Cape Yakataga, and is northeastward offshore (sheets 1-3; fig. 4). The offshore structure is tightly folded on seismic section 406, becomes much more gently folded on sections 407 and 432 , and dies out east of section 408 (sheets 1-3).
Absence of thinning in strata at the north end of the section onto anticline A3 suggests that major uplift on this structure has occurred during post-horizon A time. However, data west of line 407 indicate that uplift on the structural continuation of anticline $\mathrm{A} 3$ also occurred during $\mathrm{B}-\mathrm{A}$ time and perhaps earlier.

In general, this seismic section shows that the northern anticlines were formed earlier than the southern anticline, although substantial Pleistocene or Holocene uplift may also have occurred on the northern structures. As on seismic section 406, structural uplift is greatest on the northernmost anticline and decreases to the south.

\section{Seismic Section 409}

Seismic section 409 crosses three anticlines, A6, A7, and A8 (fig. 4). The section apparently does not cross the zone of maximum uplift on either anticline A6 or A8; recently drilled exploratory wells give an inferred position for the closure shown on the structure maps (sheets 1-3).

Horizon A forms a major unconformity over anticlines A6 and A7. Anticline A6 shows only minor faulting on the seaward flank of the structure. Minor thinning between reflectors on the flanks of the structure, and some folding of strata immediately over the A horizon, indicate that structural growth began after horizon B time and continued slightly after horizon A time. Anticline A7 has substantial offset on the mapped horizons, with a maximum of about $1,000 \mathrm{~m}$ of offset at horizon C. Reflectors over anticline A7 show substantial thinning between horizons $\mathrm{C}$ and $\mathrm{A}$ on the north side of the structure, with flat-lying strata immediately below horizon A. This pattern indicates initiation of structural growth after horizon $\mathrm{C}$ time and continuation of growth during C-B and B-A times; growth was essentially complete before horizon A time. Truncation of reflectors at the $A$ horizon on both anticlines $A 6$ and $A 7$ indicates subaerial or glacial erosion of the crests of these structures, forming the unconformity mapped as horizon A. The unconformity over these structures is analogous to the truncation of anticlines A1 and A2 at the sea floor (record 406). The presence of flat-lying to seaward-dipping posthorizon A reflectors overlying anticlines A6 and A7 indicates major post-deformation subsidence accompanied by seaward building of the continental shelf.

Anticline $\mathrm{A} 8$ has a more complex growth history than anticlines A6 or A7. Fault offset of horizons B and C is about $1,000 \mathrm{~m}$. Reflector terminations between horizons B and C on the north flank of the structure (dashed line) indicate that deformation began after horizon $\mathrm{C}$ time and that growth was essentially complete by horizon B time. Additional folding of horizons A and B indicates uplift during post-horizon A time, but apparently rather late, because minor thinning over the structure is visible only in the upper $0.5 \mathrm{~s}$ of the seismic record. Thus, this structure shows early growth, followed by subsidence and renewed recent doming of the overlying strata. The structural features of anticline A8 change markedly to the east of this record. Whereas on record 409 the structure is a broad fold, on records 408 and 432 (not shown; see Bruns and Bayer, 1977 and sheets 1-3) the structure loses the north flank dip and takes the form of a monocline; the mapped horizons on the north side of the bounding fault are displaced sharply upward.

This seismic section illustrates a general pattern for the study area. Initial structural deformation occurred before and during $\mathrm{C}-\mathrm{B}$ time on anticlines $\mathrm{A} 7$ and $\mathrm{A} 8$. Deformation ceased on anticline $A 8$, but continued on anticline $\mathrm{A} 7$ and began on anticline $\mathrm{A} 6$ during $\mathrm{B}-\mathrm{A}$ time. Finally, only minor uplift on anticline $\mathrm{A} 6$ and doming over anticline A8 occurred during post-horizon A time, and the major deformation took place seaward of anticline A6 (line 410 , next section). Therefore, structural deformation began in the northern part of the study area and moved seaward over time. Superimposed on this pattern is renewed, primarily recent uplift on the more northerly structures, accompanied by doming of the overlying strata. Also, deformation apparently did not occur during discrete time periods, but seems to have been generally continuous since at least horizon $\mathrm{C}$ time. The $\mathrm{D}$ reflector is clearly visible at the 
south end of the record but cannot be followed with confidence through anticlines A6 and A7. Deformation may have occurred before horizon $C$ time, but data within the lower part of the seismic section are generally insufficient to resolve stratal configurations below horizon $\mathrm{C}$ and distinguishing primary reflectors within the lower $2 \mathrm{~s}$ on this record is at best difficult and perhaps impossible.

\section{Seismic Section 410}

Seismic section 410 , adjacent and parallel to section 409 , shows many of the same features and again illustrates the seaward migration of deformation over time. Horizon A is an unconformity over anticlines A6, A7, and A9. Anticline A9 is the structural extension of anticline A8 but has separate closure; as on anticline $\mathrm{A8}$, the closure shown on the structure maps (sheets 1-3) is not defined by the widely spaced seismic lines but inferred from the position of an exploratory well.

As on section 409 , anticline A7 shows growth after horizon $\mathrm{C}$ time, continuing through $\mathrm{C}-\mathrm{B}$ and $\mathrm{B}-\mathrm{A}$ time. Maximum displacement across the bounding fault is about 500 $\mathrm{m}$. Anticline A9 is similar to A8 in that early growth is followed by additional doming of post-horizon A reflectors. Slope anticline SA2 shows post-horizon B growth, and the attitude of reflectors on the north side of the anticline just above horizon A shows a progression from tilted to untilted, seaward dipping reflectors thus, indicating cessation of growth, and infill and overtopping of the structure with recent sedimentary deposits during post-horizon A time. The thickness of the gently dipping post-horizon A strata over and around anticlines SA2, A6, and A7 indicates subsidence, rapid deposition, and seaward progradation of the continental shelf. Reflectors at the south end of the record, and additional data over the continental slope (T. R. Bruns, unpub. data, 1978), indicate structural deformation on anticlines seaward of this line has occurred after deformation on slope anticline SA2 ceased.

This seismic section also illustrates the water-bottom or interbed-multiple problem. Between anticlines A6 and SA2, the increasing water depth creates a set of southdipping multiples that cut across and obscure the primary reflectors. A more subtle problem is observed between horizons $\mathrm{B}$ and $\mathrm{A}$ on the north flank of anticline A7; within this interval, weak northward dipping reflectors are chosen as primary data on the base of the structural style of anticline A7 seen on section 409 and on correlations to adjacent seismic lines. The flat-lying to gently south dipping stronger reflections are interpreted as multiples generated within the overlying section.

\section{Seismic Section 412}

Seismic section 412 crosses the westward continuation of anticline A9 on the north side of the record, and a complex anticline A10 on the south side (fig. 4). Horizon C is a strong reflector that is a local unconformity; an additional unconformity, U2, is present between horizons A and B. The configuration of the reflections between these various horizons can be used to determine the structural history of the anticline.

Seismic reflectors below horizon $\mathrm{C}$ suggest that the strata are deformed and faulted. Some faults offset the C horizon but extend only slightly into the overlying strata. The absence or near absence of thinning or truncation of prehorizon $\mathrm{C}$ reflectors over anticline $\mathrm{A10}$ suggests deformation of this part of the section as a unit. Seismic reflectors in the C-B interval show onlap and thinning onto horizon $C$, and are truncated at horizon B on the north flank of anticline A10.

From these reflector configurations, the early history of anticline A10 appears to be one of major uplift and faulting before deposition of C-B strata, and more gentle uplift continuing through horizon B time. The horizon $C$ unconformity could have developed as a result of emergence and subaerial erosion, followed by renewed sedimentation, or may reflect a change in the depositional environment as a result of uplift. The second alternative is our favored interpretation, because subaerial erosion would lead to truncation of strata at the C horizon, and such truncation is not observed. This interpretation, together with the conformity of strata across the horizon, suggests that the strata below the $\mathrm{C}$ horizon were initially deposited in moderately deep water, perhaps on a continental slope. The truncation of reflectors at horizon $B$ on the north flank of anticline A10 suggests continued uplift during C-B time, and emergence of the anticline during late $C-B$ time. The unconformable segment of horizon B over the anticline was probably formed by subaerial erosion.

Seismic reflectors in the B-U2 interval show onlap onto anticline $\mathrm{A10}$, and the sequence thins over the top of the anticline. On this line, it is difficult to determine whether this sequence indicates continuing structural growth on the anticline or sedimentary infilling behind the anticline. However, the B-U2 sequence on seismic section 414 (see next section) shows marked subsidence. Therefore, we conclude that uplift on anticline A10 ceased by about horizon B time and that the B-U2 sequence was deposited behind and around the anticline.

Seismic reflectors in the U2-A interval show strong downlap onto the U2 horizon north of anticline A10 and minor onlap onto the anticline within the lowermost part of the interval. Strata within the interval thicken seaward, and reflectors are generally conformable over the top of the anticline. This configuration indicates major subsidence of anticline A10 and of strata beneath the seaward part of the seismic section during U2-A time. Subsidence was accompanied by deposition of sediment and seaward growth of the continental shelf. The U2 unconformity probably reflects a change in the tectonic regime from uplift to subsidence.

Reflectors above horizon A are also conformable with reflectors in the U2-A interval, indicating continuing subsidence after A time. However, renewed uplift of U2-A and post-horizon A strata within very recent time has resulted in tilting of the strata, a landward shift of the anticlinal axis, and truncation of strata at the crest of the anticline.

In summary, anticline A10 shows evidence for two periods of structural growth, separated by a period of subsidence during approximately B to A time. Initial uplift on the anticline, assuming that the $\mathrm{C}$ horizon was initially flat lying or gently dipping, is about $2,000 \mathrm{~m}$ after horizon $\mathrm{C}$ time; subsidence after B time is also about $2,000 \mathrm{~m}$, followed by renewed uplift of perhaps $600 \mathrm{~m}$ at the crest of the anticline. The configuration of strata on the seaward side of the anticline and the amount of offset on the bounding fault cannot be determined from the available data.

\section{Seismic Section 414}

Seismic section 414 shows tectonic interactions on the slope-anticlinal system SA4, anticline A11, and the Kayak Island platform (fig. 4); the seaward continuation of this seismic line is discussed in the next section. Although the uplift history of anticline A11 generally resembles that of anticline A10 the timing differs somewhat, and the deformation history of anticline SA4 and the Kayak Island platform shows additional details of the shifting deformational pattern. Horizons A, B, C, and additional horizons U1 and U2 (correlative with horizon U2 on section 412) are all unconformities between the Kayak Island platform and anticline A11 but are generally conformable seaward of anticline A11. As on seismic section 412, the seismic sequences between the various horizons have distinctive reflector and truncation characteristics that indicate the depositional and tectonic history of the area. We first describe a seismic sequence or set of sequences, and then discuss the geologic history inferred for these sequences.

Data below horizon B are characterized by relatively discontinuous reflectors that complicate interpretation, except for horizon $\mathrm{C}$, which is marked by a strong continuous reflector. The section below horizon $\mathrm{C}$ appears to be generally conformable, without major faulting (except at anticline A11), unconformities, or thinning within the section; furthermore, no major truncation of section is observed at horizon $C$. The pre-horizon $\mathrm{C}$ strata appear to have 
undergone deformation essentially as a unit. Reflectors within the C-B sequence show onlap onto horizon $\mathrm{C}$ between the Kayak Island platform and the crest of anticline A11. On the north side of the seismic section, the sequence thickens and is truncated by the B and A horizons. The sequence thins over the anticline and is conformable with the overlying strata seaward of the anticline.

From these reflector configurations, the early history of anticline A11 is one of uplift during C-B time, and possibly earlier. As on seismic section 412, formation of the horizon $C$ unconformity could be due either to emergence and subaerial erosion, or to initiation of uplift with a change in depositional environment. The absence of truncation or thinning within the pre-horizon $\mathrm{C}$ strata suggests that horizon $C$ reflects initiation of uplift but that uplift was insufficient to lift these strata above sea level. In addition, the gentle truncation of landward strata within the C-B sequence at the $B$ horizon suggests uplift and erosion of these strata during late C-B time, perhaps as a result of uplift along the Kayak Island platform. Figure 8 presents a depth section of seismic record 414, and shows sequential flattening of the landwardpart on each of the unconformity horizons. Figure $8 \mathrm{~A}$ shows the reconstruction to horizon $B$ time, illustrating initial uplift of anticline A11 and late C-B time uplift of the landward part of the section. Seaward of anticline A11, deposition on the continental slope occurred with no major deformation during C-B time.

Seismic sequences between horizons $B$ and $U 1$ show onlap of B-U2 reflectors onto horizon B, onlap of U2-U1 reflectors onto the U2 horizon on the landward side of the record, and strata thickening over anticline All. Seaward of the anticline, the sequences thin, and clinoform reflectors within the U2-U1 sequence above the anticline suggest that this was the approximate position of the shelf edge. Over slope anticline SA4, the B-U1 sequence is uplifted and overlain by relatively flat-lying reflectors above horizon $U 1$ (see also seismic section 922).

The geologic history during B-U1 time suggested by these sequences (fig. $8 \mathrm{~B}, \mathrm{C}$ ) is subsidence of the continental shelf, with a hinge line in the vicinity of what is currently the Kayak Island platform. This subsidence coincides in time with strong uplift of anticlinal system SA4 on the continental slope; growth of these anticlines was essentially complete by $\mathrm{U} 1$ time. Horizon B shows a change in the tectonic regime of the continental shelf from uplift to subsidence, with a seaward shift of uplift to slope anticline SA3 (fig. 4) and more seaward anticlines. Horizon U2 most likely formed during a eustatic sea level low stand in this period of subsidence, although a short-lived uplift episode cannot be ruled out. Horizon U1 reflects the change from subsidence to uplift, coinciding with cessation of uplift on anticlines SA4. The reconstruction for this period suggests only minor uplift within the Kayak Island zone during this time (fig. 8).

Seismic sequences $\mathrm{U} 1-\mathrm{A}$ and $\mathrm{A}$-sea floor lap onto horizons U1 and A respectively on the north side of the record, and the depocenter shifts landward. These strata thin over anticline A11 and show a landward shift of the anticlinal axis relative to its position during horizon $B$ time (figs. $8 \mathrm{D}, \mathrm{E}$ ). The seismic horizons show major truncation onto the Kayak Island platform and over anticline A11. On the seaward end of the record, reflectors above the anticlinal trend comprising SA4 show little or no deformation.

The geologic history indicated by these sequences is a landward shift of deformation during horizon U1 time, as well as marked uplift of the Kayak Island platform and of anticline A11 relative to the depocenters of the U1-A and A-sea floor sequences. The unconformity segments of horizons $A$ and the sea floor most likely result from relative sea level lowstands and subaerial or glacial erosion during this time of uplift.

In summary, seismic section 414 shows a history of major uplift on anticline A11 and minor uplift toward what is now the Kayak Island platform during C-B time, a seaward shift of uplift during B-U1 time, and a landward shift after U1 time including major uplift on the Kayak Island platform and on anticline A11. Unconformities at horizons U2 and A may primarily reflect changes in sea level during a particular uplift episode, resulting in erosion or non-deposition, whereas horizons $\mathrm{C}, \mathrm{B}$, and $\mathrm{U} 1$ appear to reflect shifting uplift patterns. This general history resembles the uplift history of anticline A10. The amount of uplift on anticline A11 relative to the landward depocenter of equivalent age strata is about $1,500 \mathrm{~m}$ during $\mathrm{C}-\mathrm{B}$ time and $2,000 \mathrm{~m}$ during U1-present time, with subsidence of about $1,500 \mathrm{~m}$ between these two uplift episodes. The amount of fault offset on horizon $\mathrm{C}$ on anticline A11 is about $500-800 \mathrm{~m}$. Total offset between C horizon strata of the Yakataga segment and correlative age strata at the Kayak Island platform, assuming that correlative age strata crop out within this zone, is at least $4,000 \mathrm{~m}$. The Yakataga segment strata are being thrust beneath the Middleton segment along the Kayak Island zone (Schwab and others, 1979, 1980; Bruns and others, 1980).

\section{Seismic Section 922}

Seismic section 922, which partly overlaps and is a seaward continuation of section 414, shows the general character of deformation on anticline systems SA4 and SA5 on the continental slope (fig. 4). Horizons $\mathrm{B}$ and $\mathrm{C}$ can be traced onto the north flank of anticlinal system SA4, but cannot be correlated into the seaward end of the seismic section. The anticlinal system SA4, on this particular seismic section, consists of two separate anticlines, cut by numerous faults. Neither of the anticlines can be correlated with certainty into adjacent seismic lines. The style of deformation within this zone appears to vary rapidly along strike.

Anticline SA5 is a young structure, and even the youngest section on the north flank of the structure shows a slight northward dip. Two unconformities, SU1 and SU2, within the section landward of the anticline show its growth history, although these unconformities cannot be tied into the horizons mapped beneath the continental shelf to determine a relative age. Horizon SU2 indicates initiation of growth; strata below this horizon are relatively uniform in thickness or thicken slightly seaward, whereas strata above the horizon thin onto the anticline. Horizon SU1 reflects the cessation of rapid structural growth; strata above this horizon onlap it, show only minor thinning onto the structure, and dip more gently than strata beneath the unconformity. Minimum uplift on the SU2 unconformity, assuming initially flat bedding, is approximately $1,100 \mathrm{~m}$ relative to the depth of the SU2 horizon at its northernmost mapped position; the amount of uplift could be greater if the initial bedding dipped seaward. Uplift on the SU1 unconformity of about $170 \mathrm{~m}$, indicates only minor growth during post-SU1 time; however, the dip of strata within the SU1-sea floor section could also be depositional. Relief on anticline SA5 above the abyssal plain is about $1,300 \mathrm{~m}$ and farther to the west, as much as $2,000 \mathrm{~m}$. The crest of anticline SA5 corresponds to a major bathymetric feature, Khitrov Ridge, that extends along the continental slope south of Kayak Island for about $70 \mathrm{~km}$. The synclinal low north of anticline SA5 corresponds to Khitrov basin, a 30-km-long closed topographic low and sedimentary basin on the continental slope (Atwood and others, 1980).

\section{Seismic Section 417}

Seismic section 417 crosses the Kayak Island platform approximately $16 \mathrm{~km}$ southwest of Kayak Island. The northwest end of the record crosses part of the Middleton shelf, the shelf west of Kayak Island; the southeast end crosses the Yakataga shelf (fig. 4). Interpretation of the section is complicated by highly discontinuous seismic reflections over anticline $\mathrm{A} 12$, and by severe water-bottom and interbed(?) multiples within the upper $2 \mathrm{~s}$ at both the northwest end of the record and between the Kayak Island platform and anticline A12. The positions of horizons A, B, $C$, and D are less well controlled than on other seismic sections because only one seismic tieline to line 417 is available. In addition, three unconformity horizons, U4, U5, and U6, are interpreted in the Middleton shelf seismic sequence.

On the Yakataga shelf part of the section, horizons A, $B$, and $C$ are all unconformities. Data below horizon $C$ are relatively poor, except near the Kayak Island platform, but no major unconformities or zones of deformation are apparent. 
Seismic reflectors within the lower part of the C-B sequence show strong onlap and possibly some thinning onto horizon $C$ on the north flank of anticline A12; the upper part of the sequence is apparently conformable over the crest of the anticline. The entire sequence is truncated by horizon $\mathrm{A}$ just southwest of the Kayak Island platform. Reflectors within the B-A sequence show gentle onlap and thinning onto horizon $B$ west of anticline A12, and a conformable and thickening section over the anticline. The B-A strata are also truncated at horizon A southwest of the Kayak Island platform. Finally, reflectors above horizon A are generally conformable with it and show truncation at the sea floor and minor thinning over anticline A12.

The geologic history suggested by these sequences is uplift of anticline A12 during C-B time, and cessation of growth during late C-B tima. During B-A time, subsidence occurred over anticline A12, and major uplift within the Kayak Island zone. During horizon A time, strata below horizon A were truncated near the Kayak Island platform, probably a result of emergence and erosion. Finally, after horizon A time, renewed uplift occurred on anticline A12.

On the Middleton shelf part of the section, major uplift and truncation of strata occurred before U4 time. Strata above horizon U4 are Holocene, and the unconformity is due to glacial scour during late Pleistocene time. The U6 horizon is approximately the lowermost part of the Yakataga Formation, on the basis of a seismic tie to the Tennaco Middleton Island well (T. R. Bruns, unpub. data, 1978), and is approximately correlative in age with the $\mathrm{D}$ reflector. The Yakataga Formation is substantially thinner here than on the Yakataga shelf. A minimum estimate of structural relief across the Kayak Island zone, on the basis of the positions of horizon $\mathrm{U} 6$ and the D reflector, is approximately $5 \mathrm{~km}$; total displacement, however, is probably much greater.

Kayak Island is a zone of major structural deformation and shortening; at least 5 major thrust faults have been mapped onshore (Plafker, 1974). The offshore continuation of Kayak Island is observed in the seismic section as a zone (the Kayak Island platform) in which no seismic reflectors are present. Deformation and faulting within this zone are certainly as severe as those observed on the island.

\section{ACKNOWLEDGMENTS}

We thank M. A. Fisher, D. S. McCulloch, George Plafker, and Roland von Huene for helpful discussions and J. A. Blank, S. A. Gile and P. A. Swenson for technical aid. The manuscript was reviewed by D. S. MeCulloch and George Plafker.

\section{REFERENCES CITED}

Atwood, T. J., Bruns, T. R., Carlson, P. R., Molnis, B. F., and Plafker, George, 1981, Bathymetric maps of the northern Gulf of Alaska: U.S. Geological Survey Miscellaneous Field Studies Map MF-859, scale $1: 250,000,3$ sheets.

Bayer, K. C., Mattick, R. E., Plafker, George, and Bruns, T. R., 1978, Refraction studies between Icy Bay and Kayak Island, eastern Gulf of Alaska: U.S. Geological Survey Journal of Research, v. 6, no. 5, p. 625-636.

Beikman, H. M., 1980, Geologic map of Alaska: U.S. Geological Survey, scale $1: 2,500,000$.

Bolm, J. G., Chmelik, F. B., Stewart, G. H., Turner, R. F., Wretjen, H. H., and Wills, J. C., 1976, Geological and operational summary, Alaska stratigraphic test OCS 7560, No. 1, northern Gulf of Alaska: U.S. Geological Survey Open-File Report 76-635, 40 p.

Bruns, T. R., and Plafker, George, 1975, Preliminary structural map of part of the offshore Gulf of Alaska Tertiary province: U.S. Geological Survey Open-File Report 75-508, scale 1:500,000.

Bruns, T. R., 1979, Late Cenozoic structure of the continental margin, northern Gulf of Alaska: in Sisson, Alexander, ed., The relationship of plate tectonies to Alaskan geology and resources: Alaska Geological Society Symposium, 6th, Anchorage, 1977, Proceedings, p. I1-I30.

Bruns, T. R., 1983, Structure maps and petroleum potential of the Yakutat segment of the northern Gulf of Alaska continental margin: U.S. Geological Survey Miscellaneous Field Studies Map MF-1480, seale $1: 500,000$.

Bruns, T. R., Atwood, T. J., and Childs, J. R., 1981, Free-air gravity anomaly map, Cross Sound to Iey Bay, northern Gulf of Alaska: U.S. Geological Survey Miscellaneous Field Studies Map MF-1306, scale 1:500,000.

Bruns, T. R., and Bayer, K. C., 1977, Multichannel seismic reflection data acquired on the M/V CECIL H. GREEN in the Gulf of Alaska, June-August 1975: U.S. Geological Survey Open-File Report 77-352, 22 p.

Burkhard, Nardia, Bruns, T. R., McHendrie, A. G., and Ruppel, B. D., 1980, Map of free-air gravity anomalies, eastern Gulf of Alaska: U.S. Geological Survey Miscellaneous Field Studies Map MF-1172, scale $1: 500,000$.

Burkhard, Nardia, von Huene, R. E., McHendrie, A. G., Ruppel, B. D., and Bruns, T. R., 1980, Map of free-air gravity anomalies, western Gulf of Alaska: U.S. Geological Miscellaneous Field Studies Map MF-1173, scale 1:500,000.

Carlson, P. R., and Molnia, B. F., 1978, Minisparker profiles and sedimentologic data from R/V ACONA cruise (April 1976) in the Gulf of Alaska and Prince William Sound: U.S. Geological Survey Open-File Report 78-381, 33 p.

Carlson, P. R., Molnia, B. F., Kittleson, S. C., and Hampson, J. C. Jr., 1977, Map of distribution of bottom sediments on the continental shelf, northern Gulf of Alaska: U.S. Geological Survey Miscellaneous Field Studies Map MF876,2 sheets.

Dix, C. H., 1955, Seismic velocities from surface measurements: Geophysies, v. 20, no. 1, p. 68-86.

Fisher, M. A., 1980, Petroleum geology of Kodiak Shelf, Alaska: American Association of Petroleum Geologists Bulletin, v. 64, no. 8, p. 1140-1157.

Fisher, M. A. and von Huene, R. E., 1980, Structure of upper Cenozoic strata beneath Kodiak Shelf, Alaska: American Association of Petroleum Geologists Bulletin, v. 64 , no. 7 , p. 1014-1033.

McClellan, P. H., Arnal, R. E., Barron, J. A., von Huene, R. E., Fisher, M. A., and Moore, G. W., 1980, Biostratigraphic results of dart-coring in the western Gulf of Alaska, and their tectonic implications: U.S. Geological Survey Open-File Report 80-63, 12 p.

Molnia, B. F., Carlson, P. R., and Wright, L. H., 1978, Geophysical data from the 1975 cruise of the NOAA Ship Surveyor in the northern Gulf of Alaska: U.S. Geological Survey Open-File Report 78-209, 42 p.

Plafker, George, 1967, Geologic map of the Gulf of Alaska Tertiary province, Alaska: U.S. Geological Survey Miscellaneous Geologic Investigations Map I-484, scale $1: 500,000$.

1971, Possible future petroleum resources of Pacific margin Tertiary basin, Alaska, in Cram, I. H., ed., Future petroleum provinces of the United States-their geology and potential: American Association of Petroleum Geologists Memoir 15, v.1, p. 120-135. 1974, Preliminary geologic map of Kayak and Wingham Islands, Alaska: U.S. Geological Survey Open-File Map $74-82$, scale $1: 31,680$.

Plafker, George, and Addicott, W. O., 1976, Glaciomarine deposits of Miocene through Holocene age in the Yakataga Formation along the Gulf of Alaska margin, in Miller, T. P., ed., Recent and ancient sedimentary environments in Alaska: Alaska Geological Society Symposium, Anchorage, 1975, Proceedings, p. Q1-Q23.

Plafker, George, Bruns, T. R., Carlson, P. R., Molnia, B. F., Scott, E. W., Kahler, Roger, and Wilson, Charles, 1978a, Petroleum potential, geologic hazards, and technology for exploration in the outer continental shelf of the Gulf of Alaska Tertiary province: U.S. Geological Survey Open-File Report 78-490, 33 p.

Plafker, George, Bruns, T. R. and Page, R. A., 1975, Interim report on the petroleum resource potential and geologic hazards in the outer continental shelf of the Gulf of Alaska Tertiary province: U.S. Geological Survey OpenFile Report 75-592, 74 p. 
Plafker, George, Carlson, P. R., Coonrad, W. L., Hunt, S. J., and Quinterno, Paula, 1979, Geologic implications of 1978 outcrop sample data from the continental slope in the eastern Gulf of Alaska, in Johnson, K. M., and Williams, J. R., eds., The United States Geological Survey in Alaska: Accomplishments during 1978: U.S. Geological Survey Circular 804-B, p. B143-146.

Plafker, George, and Claypool, George, 1979, Petroleum source potential of rocks dredged from the continental slope in the eastern Gulf of Alaska: U.S. Geological Survey Open-File Report 79-295, 24 p.

Plafker, George, Hudson, Travis, Bruns T. R., and Rubin, Meyer, 1978b, Late Quaternary offset along the Fairweather fault and crustal plate interactions in southern Alaska: Canadian Journal of Earth Sciences, v. 15 , no. 5 , p. $805-816$.

Plafker, George, and Rubin, Meyer, 1978, Uplift history and earthquake recurrence as deduced from marine terraces on Middleton Island, Alaska: in Proceedings of Conference VI, Methodology for identifying seismic gaps and soon-to-break gaps: U.S. Geological Survey OpenFile Report 78-943, p. 687-721

Plafker, George, Winkler, G. R., and Claypool, George, 1980, Geology of continental slope adjacent to OCS Lease Sale 55, near Yakutat, eastern Gulf of Alaska: American Association of Petroleum Geologists Bulletin, v. 64 , no. 5 , p. 766 .

Plafker, George, Winkler, G. R., Hunt, S. J., Bartsch-Winkler, Susan, Coonrad, W. L., and Quinterno, Paula, 1978c, Outcrop samples from the continental slope in the eastern Gulf of Alaska: in Johnson, K. M., ed., the United States Geological Survey in Alaska: Accomplishments during 1977: United States Geological Survey Circular 772-B, p. B97-99

Rau, W. W., Plafker, George, and Winkler, G. R., 1977, Preliminary forminiferal biostratigraphy and correlation of selected stratigraphic sections and wells in the Gulf of Alaska Tertiary province: U.S. Geological Survey Open-File Report 77-747, 54 p.

Rogers, J. F., 1977, Implications of plate tectonies for offshore Gulf of Alaska petroleum exploration: Annual Offshore Technology Conference, 9th, Houston, Texas, 1977, Proceedings, p. 11-16.
Schwab, W. C., and Bruns, T. R., 1979, Preliminary residual magnetic map of the northern Gulf of Alaska: U.S. Geological Survey Miscellaneous Field Studies Map MF1054, scale 1:500,000.

Schwab, W. C., Bruns, T. R., and von Huene, Roland, 1980, Maps showing structural interpretation of magnetic lineaments in the northern Gulf of Alaska: U.S. Geological Survey Miscellaneous Field Studies Map MF1245 , scale $1: 1,500,000$.

Stonely, Robert, 1967, The structural development of the Gulf of Alaska sedimentary province in southern Alaska: Quarterly Journal of the Geological Society of London Quaterly Journal, v. 123, pt. 1, no. 489, p. 25-57.

Von Huene, R. E., Fisher, M. A., Bruns, T. R., and Shor, G. G. Jr., 1979, Continental margins of the Gulf of Alaska and late Cenozoic tectonic plate boundaries: in Sisson, Alexander, ed., The relationship of plate tectonics to Alaskan geology and resources: Alaska Geological Society Symposium, 6th, Anchorage, Proceedings, 1977, p. J1-J33.

Von Huene, R. E., Lathram, E. H., and Reimnitz, Erk, 1971, Possible petroleum resources of offshore Pacific-margin Tertiary basin, Alaska, in Cram, I. H., ed., Future petroleum provinces of the United States-their geology and potential: American Association of Petroleum Geologists Memoir 15, v. 1, p. 136-151.

Von Huene, R. E., Molnia, B. F., Bruns, T. R., and Carlson, P. R., 1975, Seismic profiles of the of fshore Gulf of Alaska Tertiary province, R/V THOMPSON, SeptemberOctober, 1974: U.S. Geological Survey Open-File Report 75-664, 14 p.

Von Huene, R. E., Shor, G. G. Jr., and Wageman, J., 1979, Continental margins of the eastern Gulf of Alaska and boundaries of tectonic plates, in Watkins, J. S., and Montadert, Lucien eds., Geological and geophysical investigations of continental margins: American Association of Petroleum Geologists Memoir 29, p. 273290.

Winkler, G. R., 1976, Deep sea fan deposition of the Orca Group, eastern Prince William Sound, Alaska, in Miller, T.P., ed., Recent and ancient sedimentary environments in Alaska: Alaska Geological Society Symposium, Anchorage, 1975, Proceedings, p. R1-R20. 


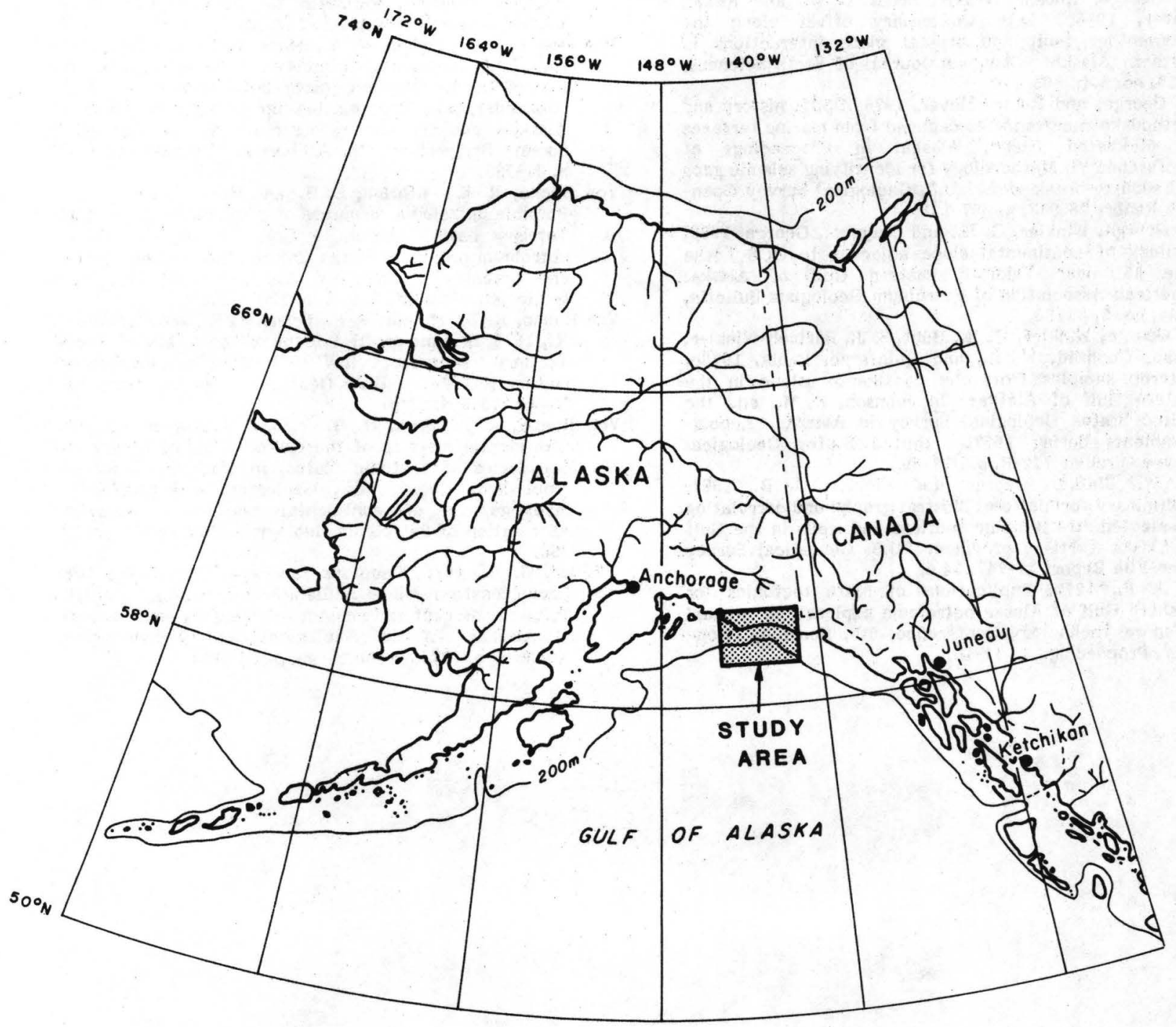

Figure 1. Index map of study area in northern Gulf of Alaska. 


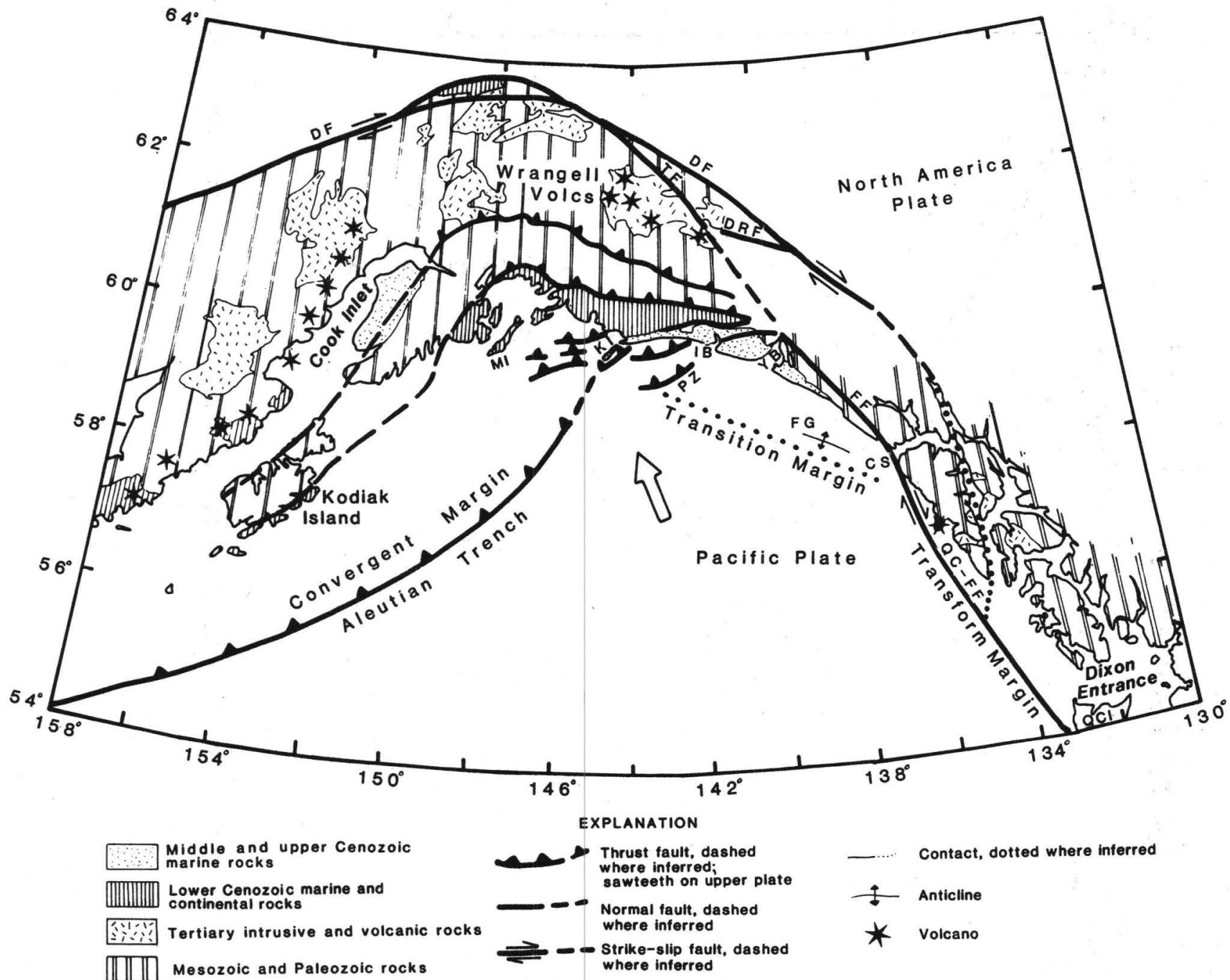

Figure 2. Simplified geologic and tectonic setting of the northern Gulf of Alaska showing structural trends and general distribution of Paleozoic, Mesozoic, and Cenozoic rocks. Geology after Beikman (1980); Pacific plate-North America plate relative-convergence vector (large arrow) from Minster and Jordan (1978). CS, Cross Sound; DF, Denali fault; DRF, Duke River fault; FF, Fairweather fault; FG, Fairweather Ground; IB, Iey Bay; KI, Kayak Island; MI, Montague Island; PZ, Pamplona zone; QCI, Queen Charlotte Islands; QC-FF, Queen Charlotte-Fairweather fault system; TF, Totschunda fault; YB, Yakutat Bay; Wrangell Voles., Wrangell volcanoes and volcanic field. 


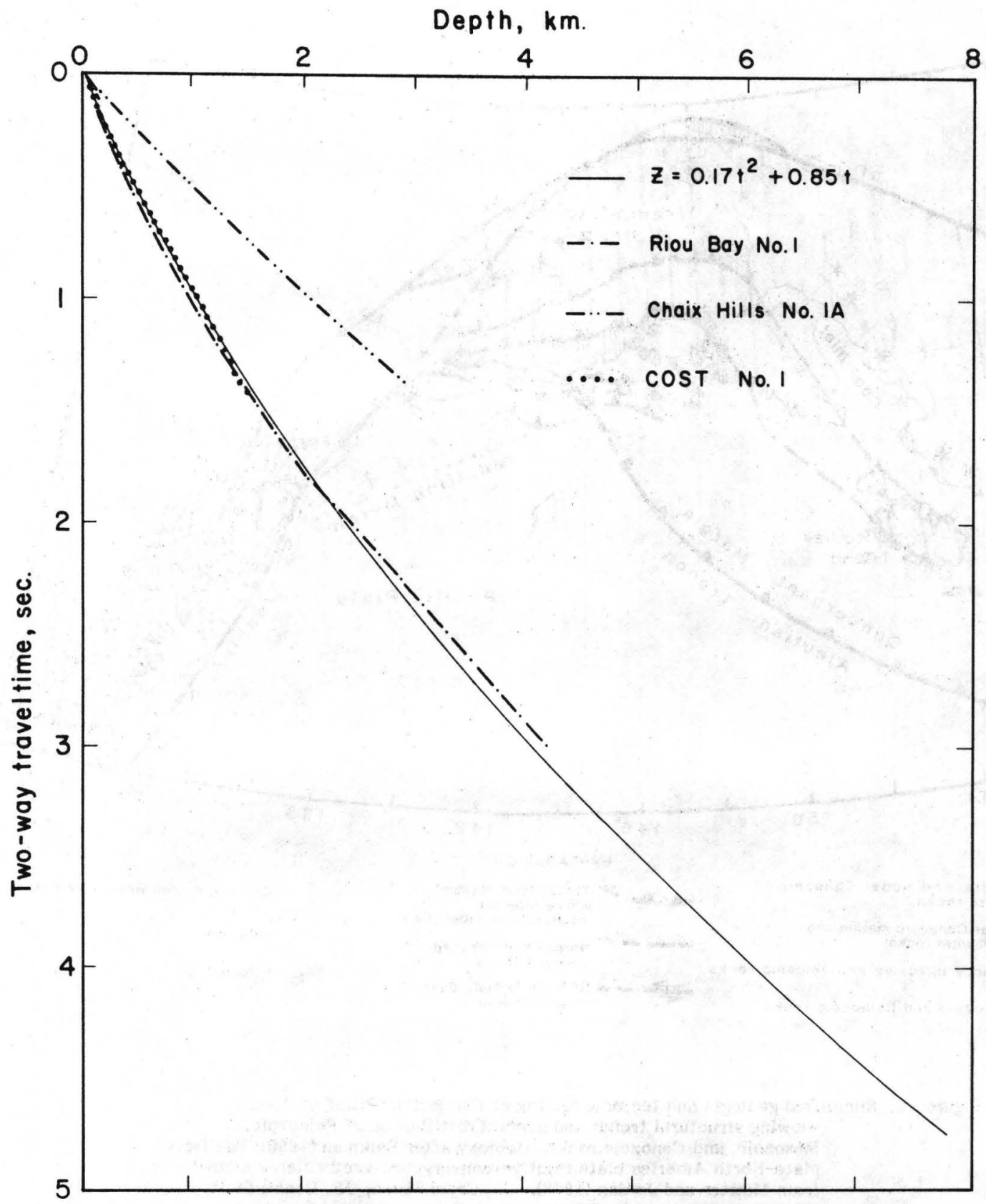

Figure 3. Time-depth curve used to convert two-way traveltime to depth for contours on sheets 1-3. Time-depth curve derived from multichannel seismic data is indicated by curve of equation $z=0.17 t^{2}+0.85 t$, where $t$ is two-way traveltime (in seconds), and $z$ is subsurface depth (in kilometers). Time-depth curves for standard Oil of California Riou Bay No. 1; (well 58) standard Oil of California Chaix Hills No. 1A (well 60) and

Continental Offshore stratigraphic Test No. 1 (well

74) wells (see sheets 1-3 for well locations) are computed from sonic logs. 


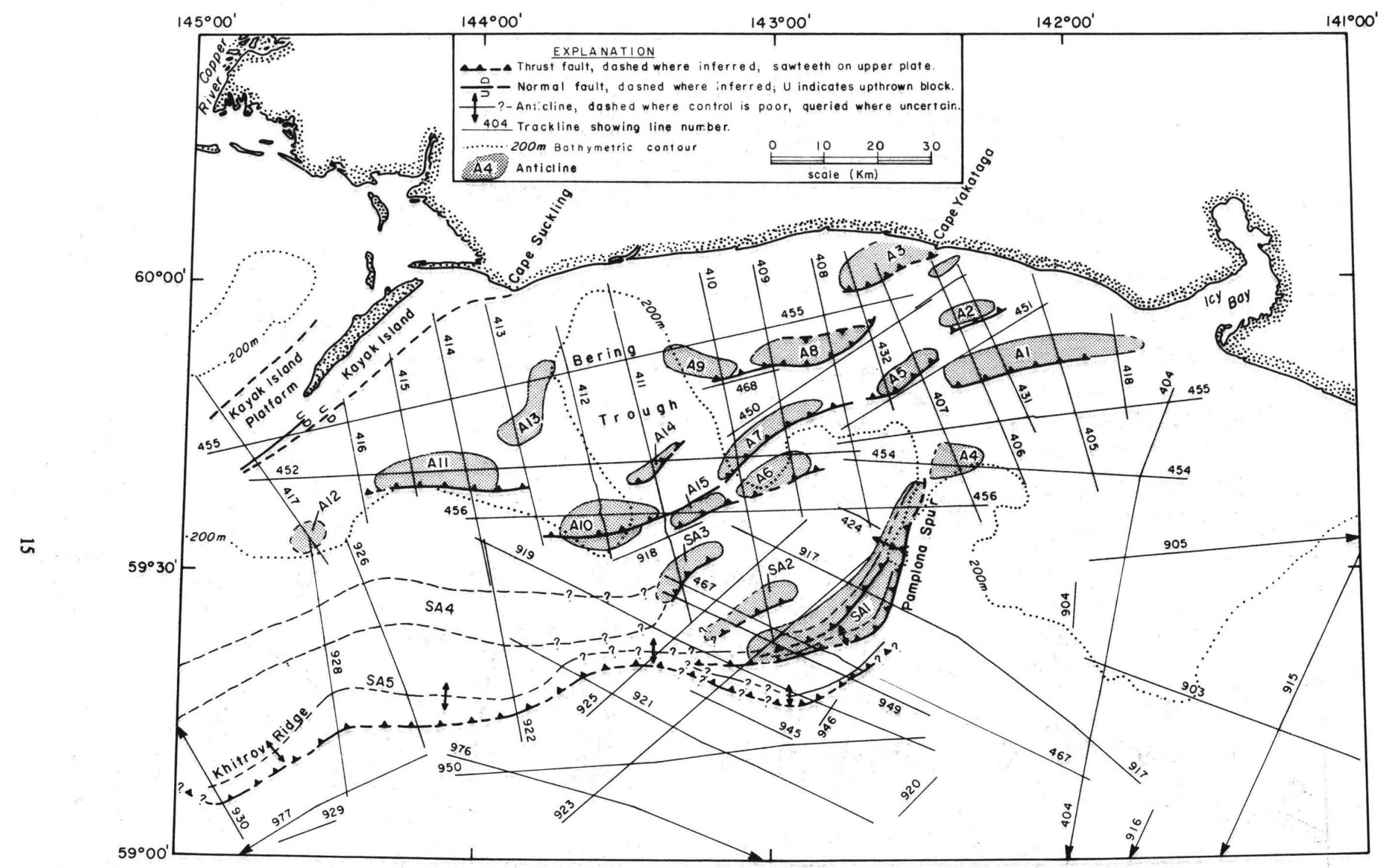

Figure 4. Outlines of major structures and structural zones of Yakataga shelf and slope. Stippled area shows general area of closure for each anticline, as determined from contours of sheets 1-3. Structural trends labeled and SA5 are areas of major anticlinal deformation number designation for zone is keyed to the text discussion and to seismic sections shown on sheet 4 . 


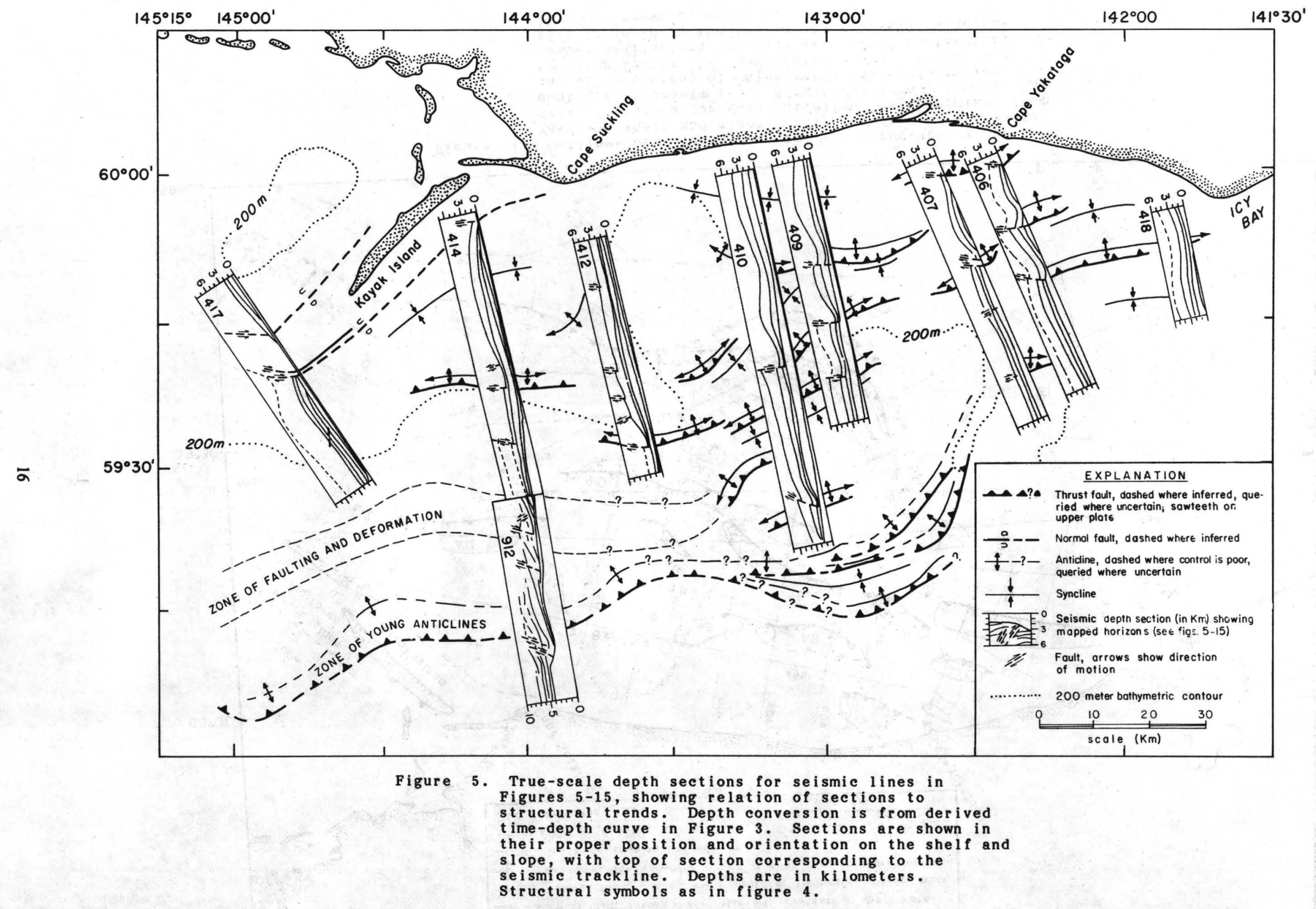




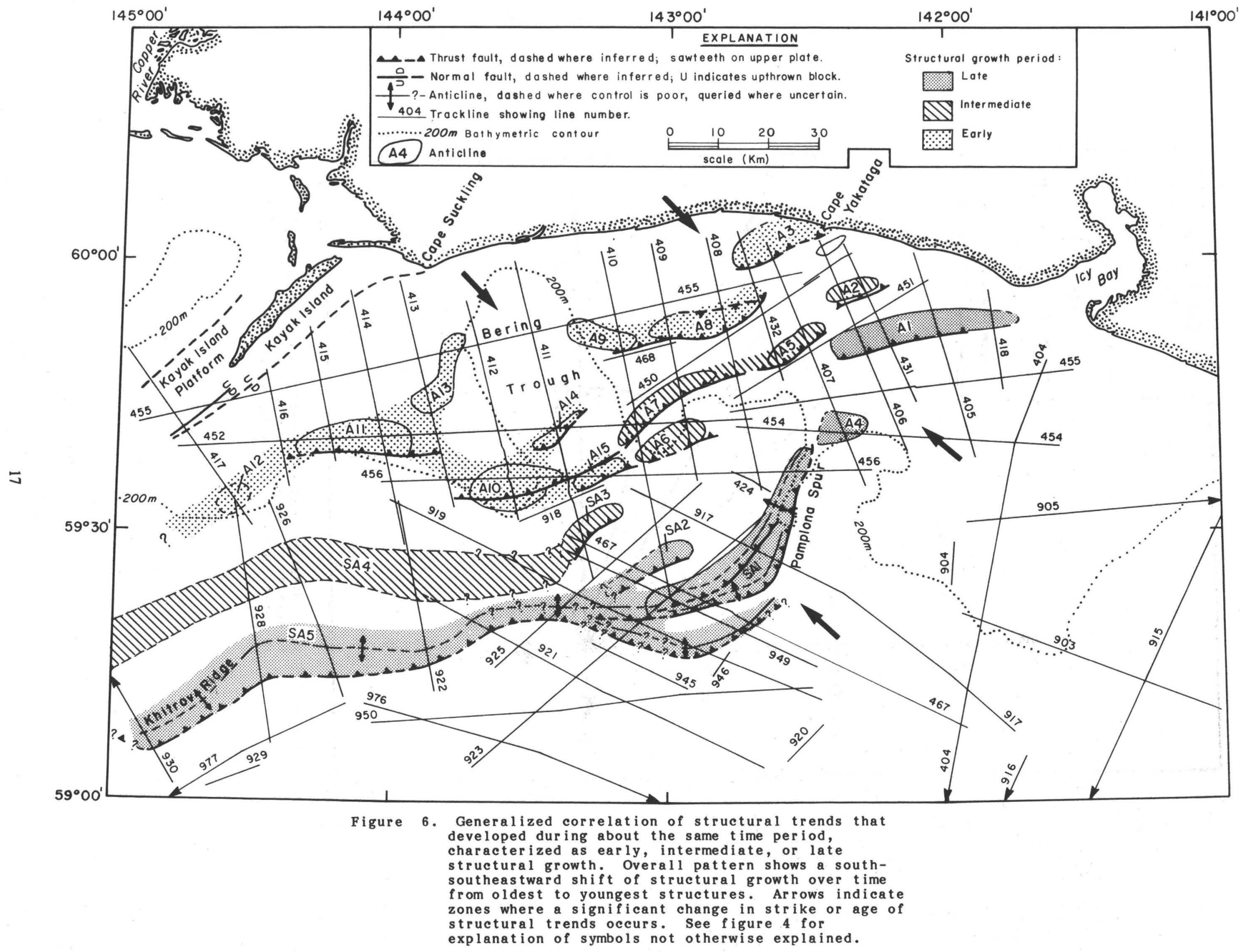




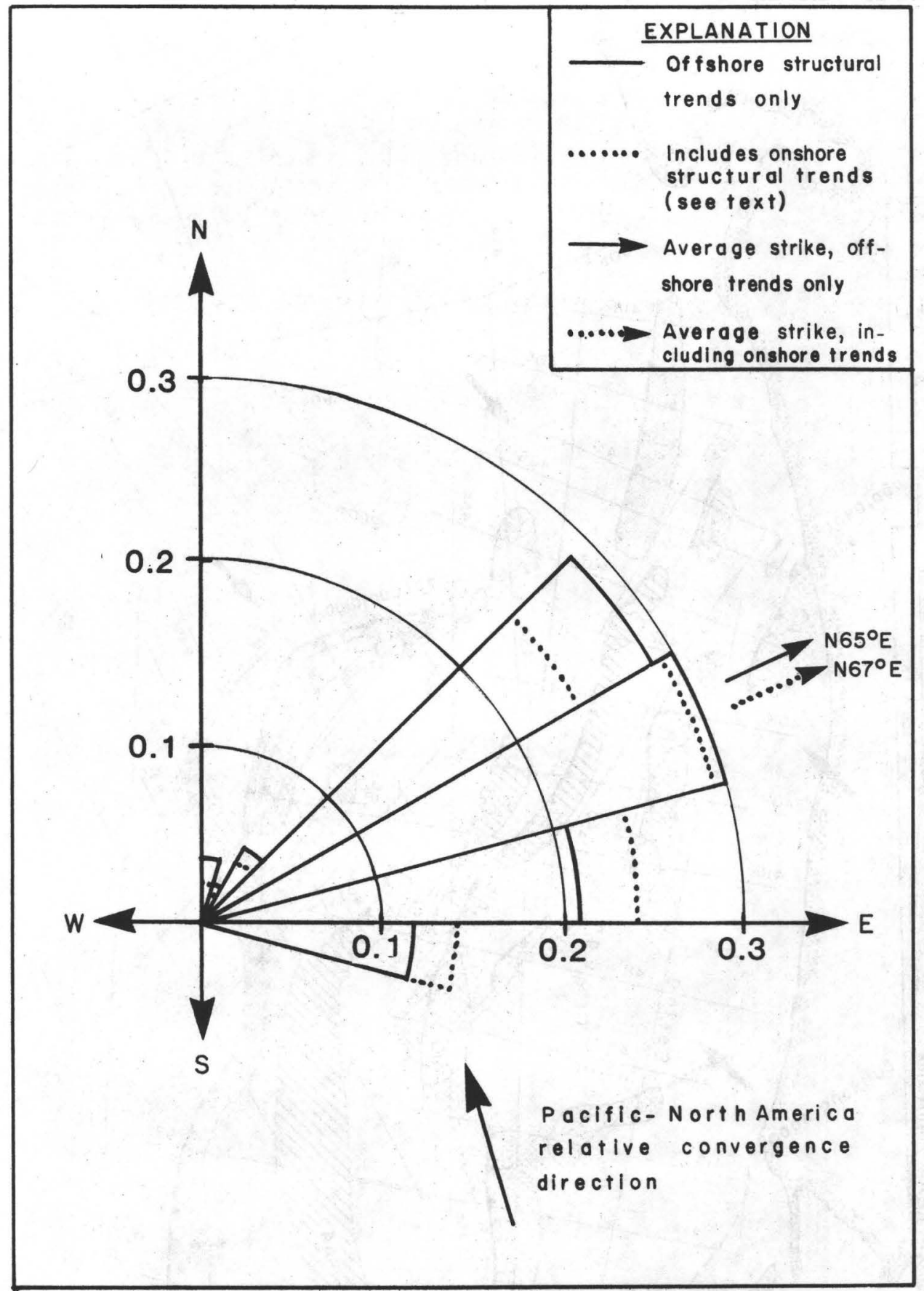

Figure 7. Rose diagram of length-weighted average strike of structures on Yakataga shelf and slope; total length is normalized to 1.0. Only positive quadrant is shown. 
ANTICLNE A11
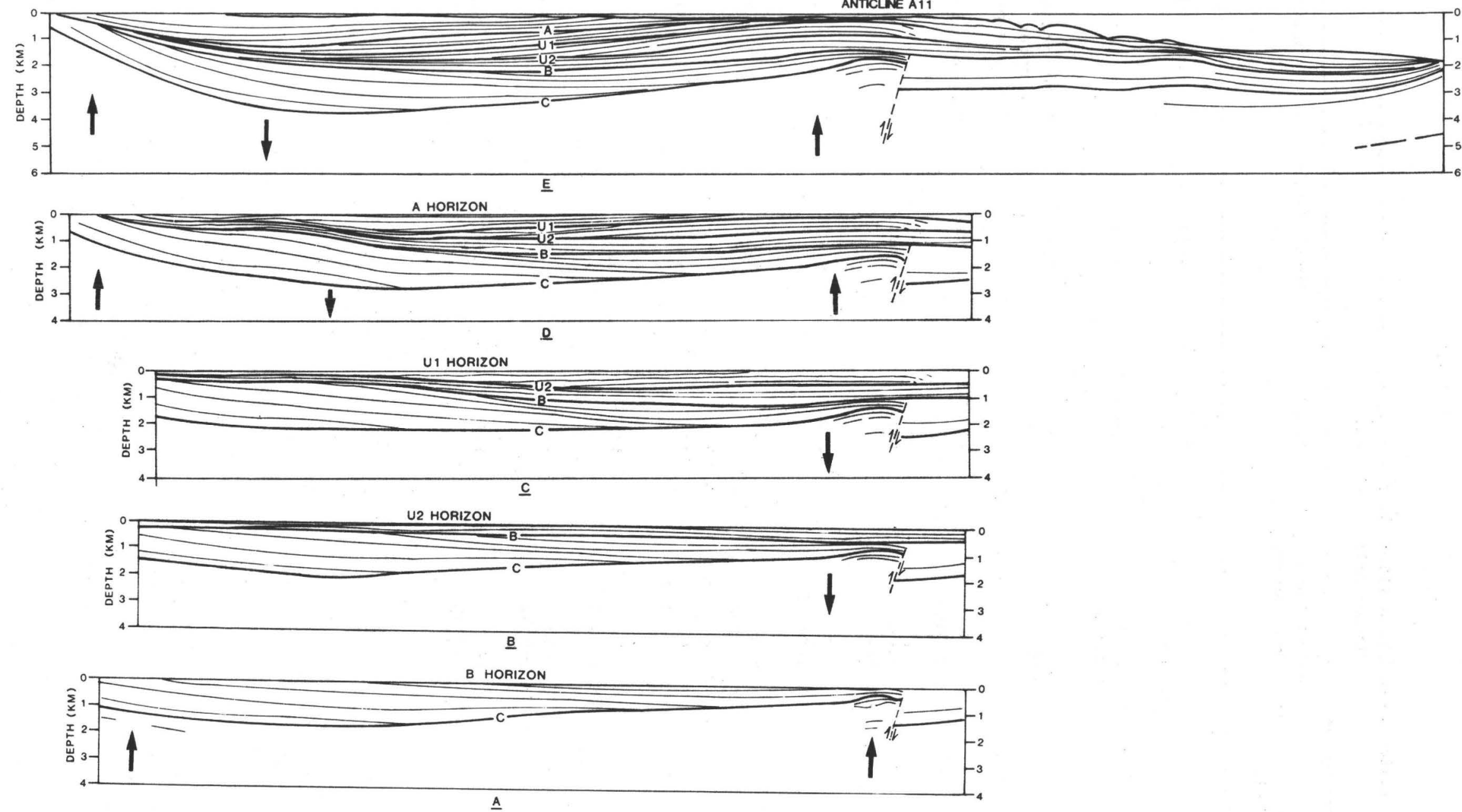

Figure 8. True-scale depth section of seismic section 414 (sheet 4) with sequential flattening of landward part of record on interpreted seismic horizons. Arrows indicate direction of relative uplift and subsidence leading to reflector configuration observed in upper seismic sequence of each diagram. 
Table 1.--Wells drilled on the Yakataga segment of the continental margin, northern Gulf of Alaska.

\begin{tabular}{|c|c|c|c|c|}
\hline $\begin{array}{l}\text { Location } \\
\text { No. on map } \\
\text { ( sheets 1-3) }\end{array}$ & $\begin{array}{l}\text { Company and } \\
\text { well designation }\end{array}$ & Years & $\begin{array}{l}\text { Total depth } \\
\text { (m) }\end{array}$ & Results \\
\hline 72 & $\begin{array}{c}\text { Exxon } \\
\text { OCS } Y-0080\end{array}$ & 1977 & 4,117 & Plugged and abandoned. \\
\hline 73 & $\begin{array}{c}\text { Shell } \\
\text { OCS Y-0011 }\end{array}$ & $1976-77$ & 4,135 & Do. \\
\hline 74 & $\begin{array}{l}\text { Arco } \\
\operatorname{cosT} 1\end{array}$ & 1975 & 1,570 & $\begin{array}{l}\text { Stratigraphic hole; } \\
\text { incomplete owing to } \\
\text { drilling problems. }\end{array}$ \\
\hline 75 & $\begin{array}{c}\text { Exxon } \\
\text { OCS } Y-0050\end{array}$ & 1977 & 3,961 & Plugged and abandoned \\
\hline 76 & $\begin{array}{c}\text { Exxon } \\
\text { OCS } \mathrm{Y}-0072\end{array}$ & 1978 & 2,998 & Do. \\
\hline 77 & $\begin{array}{c}\text { Gulf } \\
\text { OCS } Y-0059\end{array}$ & 1977 & 3,709 & Do. \\
\hline 78 & $\begin{array}{c}\text { Texaco } \\
\text { ocs } \mathrm{Y}-0046\end{array}$ & 1977 & 4,580 & Do. \\
\hline 79 & $\begin{array}{c}\text { Shell } \\
\text { OCS } Y-0014-2\end{array}$ & 1977 & 4,691 & Do. \\
\hline 80 & $\begin{array}{c}\text { Arco } \\
\text { OCS } Y-0007\end{array}$ & $1976-77$ & 5,462 & Do. \\
\hline 81 & $\begin{array}{c}\text { Texaco } \\
\text { OCS } Y-0032\end{array}$ & 1977 & 4,768 & Do. \\
\hline 82 & $\begin{array}{c}\text { Exxon } \\
\text { OcS } \mathrm{Y}-0035\end{array}$ & 1978 & 3,576 & Do. \\
\hline
\end{tabular}

